\title{
Global distribution of sea salt aerosols: new constraints from in situ and remote sensing observations
}

\author{
L. Jaeglé ${ }^{1}$, P. K. Quinn ${ }^{2}$, T. S. Bates ${ }^{2}$, B. Alexander ${ }^{1}$, and J.-T. Lin ${ }^{3}$ \\ ${ }^{1}$ Department of Atmospheric Sciences, University of Washington, Seattle, Washington, USA \\ ${ }^{2}$ Pacific Marine Environmental Laboratory, National Oceanic \& Atmospheric Administration, Seattle, Washington, USA \\ ${ }^{3}$ School of Engineering and Applied Sciences, Harvard University, Cambridge, Massachusetts, USA
}

Received: 29 September 2010 - Published in Atmos. Chem. Phys. Discuss.: 2 November 2010

Revised: 9 February 2011 - Accepted: 18 March 2011 - Published: 4 April 2011

\begin{abstract}
We combine in situ measurements of sea salt aerosols (SS) from open ocean cruises and ground-based stations together with aerosol optical depth (AOD) observations from MODIS and AERONET, and the GEOS-Chem global chemical transport model to provide new constraints on SS emissions over the world's oceans. We find that the GEOSChem model using the Gong (2003) source function overestimates cruise observations of coarse mode SS mass concentrations by factors of 2-3 at high wind speeds over the cold waters of the Southern, North Pacific and North Atlantic Oceans. Furthermore, the model systematically underestimates SS over the warm tropical waters of the Central Pacific, Atlantic, and Indian Oceans. This pattern is confirmed by SS measurements from a global network of 15 island and coastal stations. The model discrepancy at high wind speeds $\left(>6 \mathrm{~m} \mathrm{~s}^{-1}\right)$ has a clear dependence on sea surface temperature (SST). We use the cruise observations to derive an empirical SS source function depending on both wind speed and SST. Implementing this new source function in GEOS-Chem results in improved agreement with in situ observations, with a decrease in the model bias from $+64 \%$ to $+33 \%$ for the cruises and from $+32 \%$ to $-5 \%$ for the ground-based sites. We also show that the wind speedSST source function significantly improves agreement with MODIS and AERONET AOD, and provides an explanation for the high AOD observed over the tropical oceans. With the wind speed-SST formulation, global SS emissions show a small decrease from $5200 \mathrm{Mg} \mathrm{yr}^{-1}$ to $4600 \mathrm{Mg} \mathrm{yr}^{-1}$, while the $\mathrm{SS}$ burden decreases from 9.1 to $8.5 \mathrm{mg} \mathrm{m}^{-2}$. The spatial distribution of SS, however, is greatly affected, with the SS burden increasing by $50 \%$ in the tropics and decreasing by $40 \%$ at mid- and high-latitudes. Our results imply a stronger
\end{abstract}

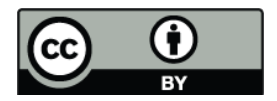

Correspondence to: L. Jaeglé

(jaegle@uw.edu) than expected halogen source from SS in the tropical marine boundary layer. They also imply stronger radiative forcing of SS in the tropics and a larger response of SS emissions to climate change than previously thought.

\section{Introduction}

Sea salt aerosols (SS) are significant players in the climate and chemistry of the marine atmosphere. SS dominate the global top-of-the-atmosphere clear-sky radiative forcing over the oceans (Haywood et al., 1999; Grini et al., 2002; Ma et al., 2008). SS are a major source of cloud condensation nuclei (O'Dowd and Smith, 1993; Quinn et al., 1998; Murphy et al., 1998; Pierce and Adams, 2006). In addition, SS act as a source of halogens and provide a large surface area for heterogeneous reactions, thereby affecting the concentrations of trace gases including ozone, reactive nitrogen, mercury, and sulfur containing compounds (e.g., Sievering et al., 1992; Vogt et al., 1999; von Glasow et al., 2004; Yang et al., 2005; Holmes et al., 2006; Read et al., 2008).

The main mechanism leading to SS production is by air bubbles bursting at the surface of the ocean as a result of wind stress (Blanchard, 1983; Monahan et al., 1986). The bubbles are formed when breaking waves entrain air to various depths. As the bubbles come back to the surface they form whitecaps and burst, leading to the injection of seawater film and jet drops into the atmosphere.

Despite their importance, SS remain one of the most poorly constrained aerosols in the global atmosphere, both in terms of their emissions and atmospheric burdens. Based on a comprehensive synthesis of observations, Lewis and Schwartz (2004) propose a best estimate global SS source of $5000 \mathrm{Tg} \mathrm{yr}^{-1}$ with a factor of 4 uncertainty. In a recent intercomparison of 15 chemical transport models (CTMs), calculated SS burdens ranged from 3 to $18 \mathrm{Tg}$ (mean \pm standard

Published by Copernicus Publications on behalf of the European Geosciences Union. 
deviation: $7.5 \pm 4 \mathrm{Tg}$ ) displaying the largest inter-model differences of all aerosol types (Textor et al., 2006).

Several confounding issues have lead to this high degree of uncertainty in the global distribution of SS. Coastal, open ocean, and laboratory measurements of SS size distribution have been used as a basis to develop multiple parameterizations to express the production flux of SS and its dependence on wind speed, with often conflicting results (e.g., Monahan et al., 1986; Smith and Harrison, 1998; Andreas, 1998; Mårtensson et al., 2003; Clarke et al., 2006). Their use in CTMs leads to factors of 2-3 differences in calculated SS concentrations (e.g., Guelle et al., 2001; Pierce and Adams, 2006). Most parameterizations assume that SS emissions are proportional to whitecap coverage, with a dependence on $10-\mathrm{m}$ wind speed of $u_{10 \mathrm{~m}}^{3.41}$ (Monahan and O'Muircheartaigh, 1980), thus small model errors in wind speed can lead to significant biases in predicted SS emissions. Even when the emissions are specified, inter model differences in transport and deposition can lead to $50-100 \%$ variations in predicted global SS burdens (Liu et al., 2007; Textor et al., 2007).

Validation of models against ground-based in-situ observations of SS can be problematic because of the potential influence of local surf conditions on coastal and island stations. Concentrations of SS over the surf are enhanced by 12 orders of magnitude (de Leeuw et al., 2000) and thus measurements near the coast might not be representative of open ocean concentrations. In addition, for many aerosol samplers the cut-off diameters are not necessarily well defined because the samplers typically operate under ambient relative humidity (RH). As most SS mass is at larger diameters $(2-20 \mu \mathrm{m})$, assumptions about cut-off diameters can lead to significant differences in modeled SS. In recent years, many modeling studies have used space-based measurements of aerosol optical depth (AOD) over the oceans for validation. However, regions of high wind speed and thus high levels of SS such as the Southern Ocean are also regions where cloud contamination likely affects the AOD retrievals from MODIS (Kaufman et al., 2005; Zhang et al., 2005; Zhang and Reid, 2006). While ground-based observations of AOD by the Aerosol Robotic NETwork (AERONET) do not suffer from such cloud contamination, there are only a few AERONET island sites where SS dominates the total AOD.

In this paper, we use open-ocean in situ measurements of SS mass concentrations from six cruises conducted by NOAA's Pacific Marine Environmental Laboratory (PMEL) between 1993 and 2008. These cruises sampled all the main ocean basins from $80^{\circ} \mathrm{N}$ to $70^{\circ} \mathrm{S}$ over a wide range of wind speeds (Fig. 1). Similar sampling protocols were used for all these shipboard measurements (including using a stable reference $\mathrm{RH}$ ) allowing for constant aerosol size segregations and helping eliminate biases in the data. This dataset will provide the cornerstone of our analysis and together with the GEOS-Chem CTM will be used to derive a new empirical SS source function applicable over a wide range of environmental conditions.
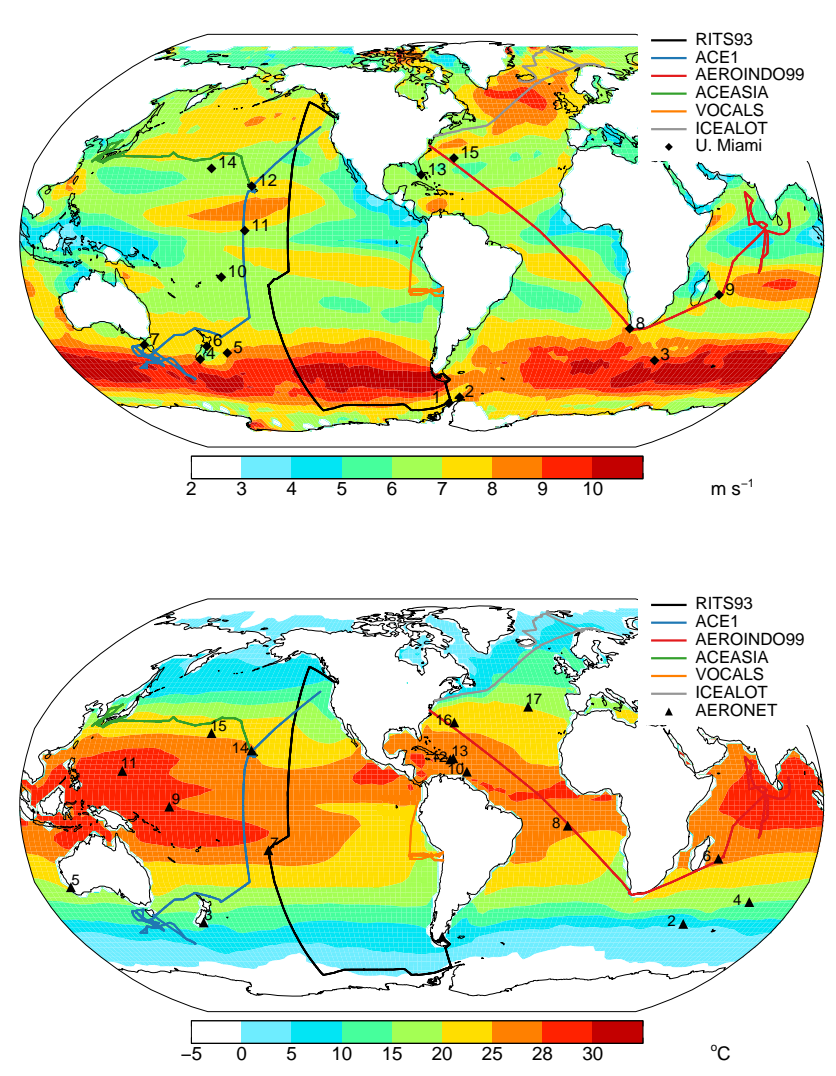

Fig. 1. Location of observations used in this study. The six PMEL open-ocean cruises are indicated with colored lines. The black diamonds in the top panel show the location of the University of Miami ground-based sites, while the black triangles in the bottom plot indicate the location of the AERONET sites. Top panel: Map annual mean surface $(10 \mathrm{~m})$ wind speeds from QuikSCAT for 2008. Bottom panel: Annual mean sea surface temperature from GEOS-5 for 2008.

Section 2 describes the GEOS-Chem SS simulation. Section 3 provides more detail on the observations used here. In Sect. 4 we compare in situ observations of SS mass concentrations with the GEOS-Chem model and derive two empirically-based source functions. These new source functions will be compared to AOD observations from MODIS and AERONET in Sect. 5. A discussion of the new SS budget is presented in Sect. 6. Summary and implications are in Sect. 7.

\section{The GEOS-Chem model}

The GEOS-Chem global tropospheric chemistry model is driven by assimilated meteorological observations from the Goddard Earth Observing System (GEOS) of the NASA Global Modeling and Assimilation Office. We use version v8-02-04 of GEOS-Chem (http://acmg.seas.harvard. edu/geos/). Two sets of meteorological fields drive the GEOS-Chem model for this study: GEOS-4 (for years prior 
to 2005) and GEOS-5 (2005-2008). The GEOS meteorological fields are provided at 3 to $6 \mathrm{~h}$ temporal resolution. The GEOS-4 fields have a horizontal resolution of $1^{\circ}$ latitude by $1.25^{\circ}$ longitude, with 55 vertical sigma levels from the surface to $0.01 \mathrm{hPa}$. The lowest $2 \mathrm{~km}$ are resolved with 5 layers. The native resolution of the GEOS- 5 fields is $0.5^{\circ} \times 0.667^{\circ}$ in the horizontal with 72 hybrid eta vertical levels, extending from the surface up to $0.01 \mathrm{hPa}$ (including 14 levels between the surface and $2 \mathrm{~km}$ altitude). For our simulations, we degrade the fields to a $2^{\circ} \times 2.5^{\circ}$ horizontal resolution. We also degrade the vertical resolution in the stratosphere, leading to 30 vertical levels in GEOS-4 and 47 levels for GEOS-5. The sea surface temperatures are derived from the weekly $1^{\circ}$ Reynolds data set (Reynolds et al., 2002). They are updated every time step using linear interpolation in time.

\subsection{Sea salt simulation}

The sea salt simulation in the GEOS-Chem model was first implemented by Alexander et al. (2005) using the source function described by Monahan et al. (1986). In this work we have implemented the formulation of Gong (2003), which is based on Monahan et al. (1986), but improves the simulation of SS with dry radii smaller than $0.1 \mu \mathrm{m}$. The Gong (2003) formulation expresses the density function $d F / d r_{80}$ (in units of particles $\mathrm{m}^{-2} \mathrm{~s}^{-1} \mu \mathrm{m}^{-1}$ ) as follows:

$$
\frac{d F}{d r_{80}}=1.373 u_{10 \mathrm{~m}}^{3.41} r_{80}^{-A}\left(1+0.057 r_{80}^{3.45}\right) \times 10^{1.607 e^{-B^{2}}}
$$

where $A=4.7\left(1+\Theta r_{80}\right)^{-0.017 r_{80}^{-1.44}}, B=\left[0.433-\log _{10}\left(r_{80}\right)\right] /$ $0.433, r_{80}$ is the particle radius at $\mathrm{RH}=80 \%$ (with $r_{80} \sim$ $2 r_{\mathrm{dry}}$ ) and $u_{10 \mathrm{~m}}$ is the 10 -meter wind speed. The parameter $\Theta$ is an adjustable parameter, which controls the shape of the size distribution of submicron aerosols. In order to match field observations reported by O'Dowd et al. (1997), Gong (2003) recommends $\Theta=30$, which is the value we use here.

Over land, SS dry deposition velocities, $v_{\mathrm{d}}$, are calculated with the size-dependent scheme of Zhang et al. (2001), which is based on the Slinn (1982) model for vegetated canopies. We take into account the hygroscopic growth as a function of RH (Gerber, 1985). Over the ocean, we have implemented the Slinn and Slinn (1980) deposition model for natural waters. The Slinn and Slinn (1980) model divides the marine boundary layer into a viscous sublayer, with a thickness of $\sim 0.1-1 \mathrm{~mm}$, and a surface layer above. Following the recommendation of Lewis and Schwartz (2004), we assume $\mathrm{RH}=98 \%$ in the viscous sublayer because of its proximity to the ocean surface, while for the surface layer we assume ambient RH. Brownian diffusion, impaction, and gravitational sedimentation are taken into account in the viscous sublayer. In the surface layer, deposition is controlled by turbulent diffusion and by gravitational settling. The resulting $v_{\mathrm{d}}$ has a strong dependence on wind speed and on aerosol size (and thus local RH). For example, $v_{\mathrm{d}}$ increases by an order of magnitude as $r_{\text {dry }}$ increases from 1 to $4 \mu \mathrm{m}$ for $u_{10 \mathrm{~m}}=9 \mathrm{~m} \mathrm{~s}^{-1}$ and $\mathrm{RH}=80 \%$. To take this dependence into account, we integrate $v_{\mathrm{d}}$ over each size bin using a bimodal size distribution for SS including growth as a function of local RH. We assume the same size distribution as for the optical properties (described below). Sedimentation of SS is calculated throughout the atmospheric column based on the Stokes velocity scheme. Wet deposition of SS includes scavenging in convective updrafts, as well as rainout and washout (Liu et al., 2001).

\subsection{Sea salt optical properties}

The AOD is calculated at $550 \mathrm{~nm}$ from Mie theory using the mass concentrations, extinction efficiency and particle mass density (Martin et al., 2003). The calculation takes into account growth of aerosols as a function of $\mathrm{RH}$. The original size distribution of SS in GEOS-Chem were taken from the Global Aerosol Data Set (GADS) (Köpke et al., 1997), assuming a dry geometric radius $r_{\mathrm{dg}}=0.209$ and $1.75 \mu \mathrm{m}$ for accumulation and coarse mode SS, respectively, with a geometric standard deviation $\sigma_{\mathrm{g}}=2.03 \mu \mathrm{m}$. Observations suggest that these values are too high.

Based on cruises in the remote Pacific Ocean, Quinn et al. (1996) report a narrow range of $r_{\mathrm{g}}=0.075-0.095 \mu \mathrm{m}$ and $\sigma_{\mathrm{g}}=1.4-1.54 \mu \mathrm{m}$ under near-dry conditions $(30 \% \mathrm{RH})$. SS accounted for $55 \%$ of the dry accumulation mode mass. Taking the mid-values of these ranges, we use $r_{\mathrm{gd}}=0.085 \mu \mathrm{m}$ and $\sigma_{\mathrm{g}}=1.5 \mu \mathrm{m}$ for the size distribution of accumulation mode SS in GEOS-Chem. Reid et al. (2006) and Reid and Peters (2007) recently compiled and evaluated a vast set of observed size distributions for coarse mode SS. Their best estimate for volume median diameter (VMD) is $4.5 \pm 1 \mu \mathrm{m}$ at $80 \% \mathrm{RH}$ and $\sigma_{\mathrm{g}} \sim 1.8-2 \mu \mathrm{m}$. Assuming $\sigma_{\mathrm{g}}=1.8 \mu \mathrm{m}$, we can convert this VMD to the geometric mean number diameter $\left(\mathrm{VMD}=D_{\mathrm{g}} \exp \left(3\left(\ln \left(\sigma_{\mathrm{g}}\right)\right)^{2}\right)\right.$. Taking into account the factor of 2 hygroscopic growth of SS between 0 and $80 \%$ $\mathrm{RH}$, this corresponds to $r_{\mathrm{gd}}=0.4 \mu \mathrm{m}$. With these new assumptions for the size distribution of SS, the effective radii for accumulation and coarse mode SS are $r_{\text {eff }}=0.25 \mu \mathrm{m}$ and $r_{\text {eff }}=1.9 \mu \mathrm{m}$ at $\mathrm{RH}=80 \%$.

We calculate a mass extinction efficiency $(55 \% \mathrm{RH})$ for accumulation mode SS of $4.1 \mathrm{~m}^{2} \mathrm{~g}^{-1}$ at $550 \mathrm{~nm}$, consistent with values inferred from SS mass and extinction observations, which range from 3.1 to $6.6 \mathrm{~m}^{2} \mathrm{~g}^{-1}$ (Quinn and Bates, 2005). The mass extinction efficiency for coarse mode SS is $1.1 \mathrm{~m}^{2} \mathrm{~g}^{-1}$, also within the range of observed values, 1.0 to $1.7 \mathrm{~m}^{2} \mathrm{~g}^{-1}$ (Quinn and Bates, 2005).

\section{$2.3 \quad 10-m$ wind speed and vertical mixing}

Equation (1) has a strong dependence on 10-m wind speed and thus biases in wind speed can lead to significant errors in SS emissions. In Fig. 2, we assess the robustness of our modeled winds by comparing annual mean GEOS-5 10-m winds to NCEP reanalysis (Kalnay et al., 1996) and 

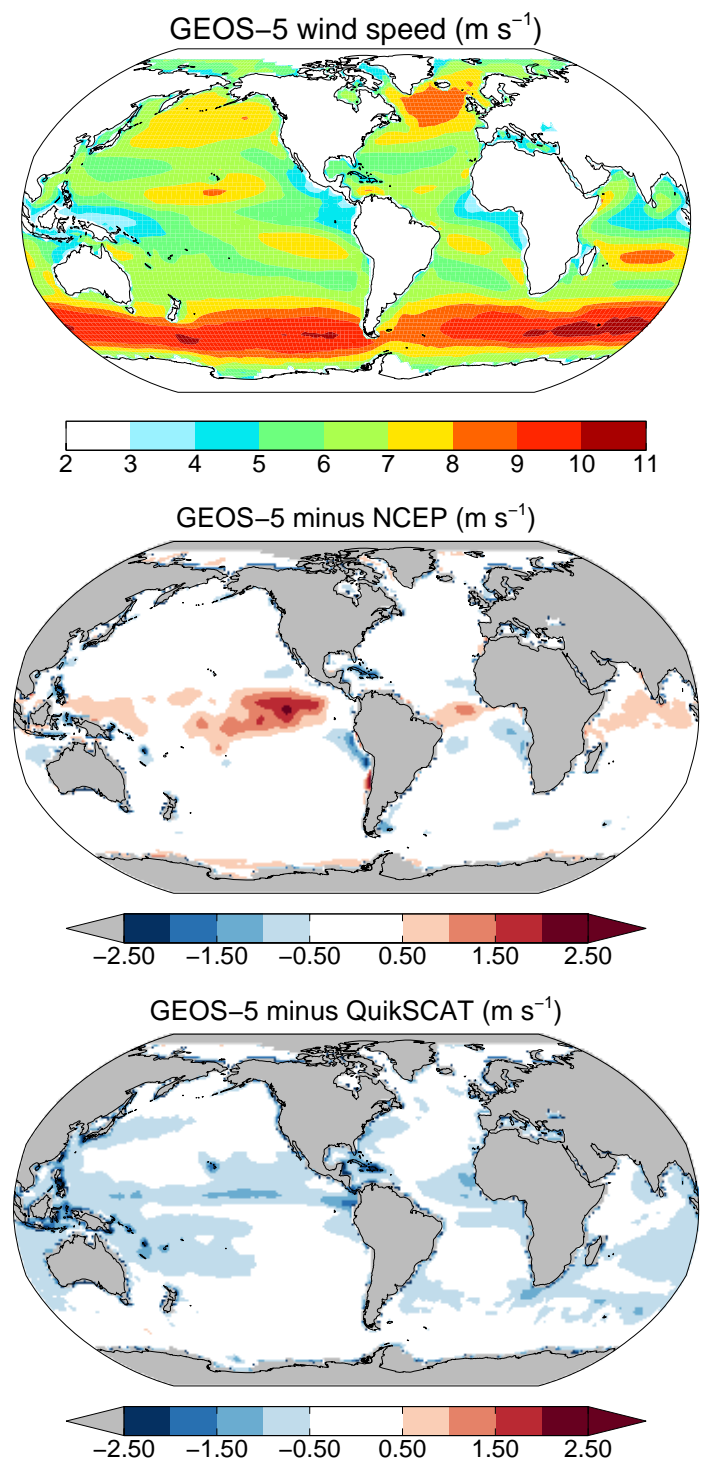

Fig. 2. Comparison of annual mean wind speed $\left(\mathrm{m} \mathrm{s}^{-1}\right)$ for GEOS5, NCEP, and QuikSCAT for 2005-2008. Top panel: Annual mean wind speed for GEOS-5. Middle panel: GEOS-5 minus NCEP winds. Bottom panel: GEOS-5 minus QuikSCAT winds.

to winds retrieved from the SeaWinds scatterometer onboard the QuikSCAT satellite. We use the QuikSCAT Mean Wind Field product from Ifremer (MWF, 2002). The annual mean wind speeds were calculated from the daily values for 2005-2008. Both the QuikSCAT (horizontal resolution of $0.5^{\circ} \times 0.5^{\circ}$ ) and NCEP (T62 Gaussian grid) surface winds are regridded onto the GEOS $2^{\circ} \times 2.5^{\circ}$ grid. The three datasets agree remarkably well. The mean annual bias between GEOS- 5 and NCEP is $+0.03 \mathrm{~m} \mathrm{~s}^{-1}$ (GEOS-5 minus NCEP, area weighted), with GEOS- 5 being $1.4 \%$ higher than NCEP. GEOS-5 and NCEP are generally within $0.5 \mathrm{~m} \mathrm{~s}^{-1}$ of each other over most of the oceans (Fig. 2, middle panel). The only regions of discrepancy are areas of low wind speeds near the Equator, which could be due to small discrepancies in the location of the InterTropical Convergence Zone (ITCZ). As SS emissions are proportional to $u_{10 \mathrm{~m}}^{3.41}$ we examine the annual mean SS emission potential (sum of areaweighted daily $u_{10 \mathrm{~m}}^{3.41}$ over the oceans), finding a $+3.6 \%$ bias in GEOS-5 relative to NCEP. Relative to the QuikSCAT dataset, GEOS-5 has a $-0.49 \mathrm{~m} \mathrm{~s}^{-1}$ bias globally $(-6.5 \%$ for $u_{10 \mathrm{~m}}$ and $-23 \%$ for $\left.u_{10 \mathrm{~m}}^{3.41}\right)$. The largest biases are on the order of $0.5-1 \mathrm{~m} \mathrm{~s}^{-1}$ co-located with relatively low wind speed regions where scatterometer retrievals typically overestimate buoy observations (Bentamy et al., 1999). We also examine the impact of degrading our horizontal resolution by comparing the SS emission potential at different resolutions for QuikSCAT $\left(2^{\circ} \times 2.5^{\circ}\right.$ and $\left.1^{\circ} \times 1^{\circ}\right)$ and GEOS-5 $\left(2^{\circ} \times 2.5^{\circ}\right.$ and $\left.0.5^{\circ} \times 0.667^{\circ}\right)$. We find that horizontal resolution has minimal impact, affecting our daily SS emission potential by less than $4 \%$ and annual mean SS emissions potential by less than $2 \%$.

We repeated the same analysis for GEOS- 4 winds for the years 2005 and 2006 (not shown). We found that GEOS-4 winds have a global positive bias of $0.2 \mathrm{~m} \mathrm{~s}^{-1}$ (+4\% bias) compared to both NCEP and GEOS-5 winds, systematically overestimating winds over the Southern Ocean by $0.5-$ $1 \mathrm{~m} \mathrm{~s}^{-1}$. The SS emission potential calculated with GEOS-4 winds is $18 \%$ higher than GEOS-5 and NCEP. Both GEOS4 and GEOS-5 do assimilate QuikSCAT as well as other surface wind observations from other satellites, ships, and buoys. However, the improved vertical resolution, turbulence model, and observation operator for scatterometer winds in GEOS-5 has led to improvements in the 10-m winds in the analyses over GEOS-4 (S. Pawson and A. Molod, personal communication, 2011). A further validation of the GEOS-4 and GEOS-5 winds will be conducted by comparison to ship observations in Sect. 4.1.

Another difference between in GEOS-Chem when driven by GEOS-4 or GEOS-5 comes from divergent assumptions for vertical mixing in the boundary layer. When GEOSChem is driven by GEOS-4 fields, the assumption is that concentrations, surface emissions, and dry deposition are distributed evenly below the top of the boundary layer. The resulting mixing is thus likely to be too efficient. GEOS5 allows for the inclusion of a non-local parameterization of boundary layer mixing, which is more realistic (Lin and McElroy, 2010). When we conducted 1-year SS simulations using meteorological fields for the same year (2005), we found that SS surface mass concentrations calculated with GEOS-4 were $40 \%$ higher than those with GEOS-5. Most of this GEOS-4 overestimate is due to its too fast winds relative to GEOS-5.

In this paper we will use the GEOS-5 simulation as our standard reference. However to compare to cruise observations prior to 2004 we have to rely on the GEOS-4 fields (at the time of this work, GEOS-5 analyses were not available prior to 2004). Thus all the GEOS-4 calculated SS surface 
concentrations are scaled by a factor of 0.7 in order to have consistency with the simulations conducted with the GEOS-5 fields.

\subsection{Simulations conducted in this work}

For comparison to the PMEL cruise observations, we conduct SS-only simulations corresponding to the time period of each cruise assuming one size bin for accumulation mode SS and one for coarse mode SS. The assumed size bins correspond to the cut-off diameters of the samplers (see Sect. 3.1). The model is sampled every $30 \mathrm{~min}$ at the closest time and location along the cruise track. The modelled SS concentrations are then averaged over the measurement sampling times, which range from $2 \mathrm{~h}$ to $24 \mathrm{~h}$.

MODIS and AERONET measure total AOD, thus for comparison to GEOS-Chem we need to calculate the concentrations and AOD of all aerosols. In addition to SS, we also consider the contributions from dust, black carbon and organic carbon aerosols as well as from sulfate, nitrate, and ammonium aerosols. We have thus conducted a coupled aerosol-oxidant simulation for 2005-2008. For this simulation, we used three SS size bins: one accumulation mode $\left(r_{\text {dry }}=0.01-0.5 \mu \mathrm{m}\right)$ and two for coarse mode aerosols $(0.5-$ $4 \mu \mathrm{m}$ and $4-10 \mu \mathrm{m})$. We have separated the coarse mode SS into two bins as the larger aerosols $(4-10 \mu \mathrm{m})$ have a much shorter lifetime than the smaller coarse mode SS. The two coarse mode bins use the same optical properties (Sect. 2.2). The aerosol-oxidant simulation in GEOS-Chem is described in detail in Bey et al. (2001), Martin et al. (2003), and Park et al. (2004).

In addition to standard model simulations using the Gong (2003) SS source function (MODEL-STD), we will also conduct two additional SS simulations with empirically-derived source functions (Table 1), as discussed in Sect. 4. Simulations based on three other source functions (Monahan et al., 1986; Mårtensson et al., 2003; Clarke et al., 2006) are presented in the Supplement.

\section{Observations}

\subsection{In situ observations of sea salt concentrations}

We analyze SS observations collected on six PMEL cruises: the Radiatively Important Trace Species cruise in March-May 1993 (RITS93), the First Aerosol Characterization Experiment (ACE1) cruise in October-December 1995, the AEROSOLS99 and Indian Ocean Experiment (AEROINDO99) in January-March 1999, the Asian Pacific Regional Aerosol Characterization Experiment (ACEAsia) in March-April 2001, the International Chemistry Experiment in the Arctic LOwer Troposphere (ICEALOT) in March-April 2008, and the VAMOS Ocean-Cloud-
Atmosphere-Land Study (VOCALS) in October-December 2008 (Table 2). Figure 1 displays the cruise tracks for these six experiments.

Two-stage multijet cascade impactors (Berner et al., 1979) were used to determine the inorganic ion concentrations of submicron and supermicron aerosols for all cruises, except RITS93 for which a seven-stage impactor was used. The air drawn into the instrument inlet was kept at a constant relative humidity (RH $=30 \%$ for RITS $93,30-45 \%$ for ACE1, $55 \%$ for ACE-Asia, AEROINDO99 and VOCALS, and $<25 \%$ for ICEALOT). Aerosol particles were sampled $18 \mathrm{~m}$ above the sea surface through a heated mast that extended $5 \mathrm{~m}$ above the aerosol measurement container. The mast was capped with a cone-shaped inlet nozzle that was rotated into the relative wind to maintain nominally isokinetic flow and minimize the loss of coarse mode particles. The transmission efficiency of the inlet was $>90 \%$ for particles with an aerodynamic diameter of $6.5 \mu \mathrm{m}$ (Bates et al., 2002). The 50\% aerodynamic accumulation and coarse mode cut-off diameters were 1.1 and $10 \mu \mathrm{m}$ for all cruises except RITS93 for which $1 \mu \mathrm{m}$ and $8 \mu \mathrm{m}$ were used. For comparison to aerosol mass calculated with GEOS-Chem, we convert these aerodynamic cut-off diameters at instrumental RH to dry geometric radii. This conversion is done using observed aerosol densities of $1.6 \mathrm{~g} \mathrm{~m}^{-3}$ and $1.3 \mathrm{~g} \mathrm{~m}^{-3}$ for accumulation and coarse mode aerosols under marine conditions (Quinn et al., 2001) and assuming a hygroscopic growth of 1.4 for sea salt and 1.15 for sulfate aerosols at 50\% RH (Berg et al., 1998). We find that the sampling conditions during these cruises correspond approximately to dry geometric radii of $0.3 \mu \mathrm{m}$ and $3 \mu \mathrm{m}$. For the ICEALOT and RITS93 the air was sampled at near dry conditions. Assuming an aerosol density of $1.7 \mathrm{~g} \mathrm{~m}^{-3}$ (Quinn et al., 1996) and a dry aerosol, we obtain dry geometric radii of 0.3 and $3.05 \mu \mathrm{m}$ for RITS 93 and 0.4 and $3.8 \mu \mathrm{m}$ for ICEALOT. Thus for ICEALOT we will use $0.01-0.4 \mu \mathrm{m}$ and $0.4-3.8 \mu \mathrm{m}$ size bins for accumulation mode and coarse mode SS in the GEOS-Chem calculations. For all other cruises we use model bins of $0.01-0.3 \mu \mathrm{m}$ (accumulation mode) and 0.3-3 $\mu \mathrm{m}$ (coarse mode).

Concentrations of $\mathrm{Na}^{+}$and $\mathrm{Cl}^{-}$are measured by ion chromatography (Quinn et al., 1998). Assuming that all measured $\mathrm{Na}^{+}$and $\mathrm{Cl}^{-}$are derived from seawater, SS concentrations are calculated from: SS $\left(\mu \mathrm{g} \mathrm{m}^{-3}\right)=\mathrm{Cl}^{-}\left(\mu \mathrm{g} \mathrm{m}^{-3}\right)$ $+1.47 \times \mathrm{Na}^{+}\left(\mu \mathrm{g} \mathrm{m}^{-3}\right)$ (Quinn and Bates, 2005). The sampling period of the impactor ranged from 2 to $24 \mathrm{~h}$, with a mean of $11 \mathrm{~h}$. For an average ship speed of 13 knots $\left(24 \mathrm{~km} \mathrm{~h}^{-1}\right)$ this corresponds to measuring SS concentrations over $50-580 \mathrm{~km}$, with a mean of $265 \mathrm{~km}$. This scale is comparable to our model grid-size ( $200-300 \mathrm{~km})$.

The wind speeds reported from the ships were measured by a sensor mounted on the meteorological mast at heights of 14-33 m a.s.l. depending on the cruise. We relate the ship wind speed to $10 \mathrm{~m}$ wind speed using the power law wind profile exponent of Hsu et al. (1994). 
Table 1. Simulations conducted in this work.

\begin{tabular}{lll}
\hline Model & Description & SS source function \\
\hline MODEL-STD & Standard model simulation & Gong (2003), Eq. (1) \\
MODEL-U2 & Simulation with quadratic wind speed dependence & Eq. (3) \\
MODEL-SST & Simulation with sea surface temperature dependence & Eq. (4) \\
\hline
\end{tabular}

For comparison to observations each of these simulations is conducted with the appropriate bin sizes. For in situ PMEL cruises and ground-based stations we conduct simulations with two bins: $0.01-0.3 \mu \mathrm{m}$ dry radius (accumulation mode) and $0.3-3 \mu \mathrm{m}$ (coarse mode). One exception is the ICEALOT cruise for which we use $0.01-0.4 \mu \mathrm{m}$ and $0.4-3.8 \mu \mathrm{m}$. For MODIS and AERONET, we use 3 bins: one accumulation mode $(0.01-0.5 \mu \mathrm{m})$ and two coarse mode $(0.5-4 \mu \mathrm{m}$ and $4-10 \mu \mathrm{m})$ bins.

Table 2. Summary of observed wind speed, SST, and SS concentrations for the PMEL cruises.

\begin{tabular}{lllcrcc}
\hline Experiment & Date & Location & Wind & SST & $\begin{array}{c}\text { Coarse mode } \\
\text { Accumulation } \\
\text { mode SS } \\
{\left[\mu \mathrm{g} \mathrm{m}^{-3}\right]}\end{array}$ \\
\hline RITS93 & Mar-Apr 1993 & Pacific + Southern Oceans & $8.9 \pm 3.7$ & $15 \pm 11$ & $6.9 \pm 3.9$ & $0.72 \pm 0.65$ \\
ACE1 & Oct-Dec 1995 & Pacific + Southern Oceans & $7.2 \pm 2.3$ & $17 \pm 7$ & $8.0 \pm 4.6$ & $0.45 \pm 0.31$ \\
ICEALOT & Mar-Apr 2008 & N. Atlantic Ocean & $9.0 \pm 3.8$ & $4 \pm 2.5$ & $5.1 \pm 4.8$ & $0.83 \pm 0.50$ \\
AEROINDO99 & Jan-Mar 1999 & Atlantic + Indian Oceans & $5.4 \pm 2.3$ & $27 \pm 3$ & $6.6 \pm 4.7$ & $0.13 \pm 0.11$ \\
ACE-Asia & Mar-Apr 2001 & NW Pacific Ocean & $6.8 \pm 3.0$ & $17 \pm 3$ & $5.9 \pm 4.5$ & $0.23 \pm 0.14$ \\
VOCALS & Oct-Dec 2008 & SE Pacific Ocean & $6.0 \pm 1.7$ & $19 \pm 1$ & $5.2 \pm 2.3$ & $0.11 \pm 0.57$ \\
\hline
\end{tabular}

The mean and standard deviations for the wind speed and SST are averaged over the SS measurement time.

In addition, we also use in situ observations from the University of Miami network of aerosol sampling stations (Savoie and Prospero, 1977). This network includes 35 stations, which were established in the early to mid-1980s and operated until the late 1990s. Aerosols were collected by high-volume filter samplers and analyzed for the major aerosol species, including $\mathrm{Cl}^{-}$and $\mathrm{Na}^{+}$. Similarly to the PMEL observations, we calculate $\mathrm{SS}$ concentrations based on the measurements of $\mathrm{Cl}^{-}$and $\mathrm{Na}^{+}$. SS measurements at many of the coastal stations were affected by local surf conditions and are thus not representative of open ocean conditions. Thus we only use the 15 stations where the data quality was deemed acceptable by the investigators (J. Prospero, personal communication, 2010). We will compare this dataset's monthly mean SS observations, which were collected over multiple years, to monthly mean GEOS-Chem values over the years 2005-2008. We use the same size bins as for the PMEL simulations (upper dry radius cut-off of $3 \mu \mathrm{m}$ ). Given that the University of Miami samplers operated at ambient conditions ( $\mathrm{RH} \sim 80 \%$ ) with a PM10 inlet, this might lead to a slight overestimate in SS concentrations.

\subsection{AOD observations}

MODIS has been providing global measurements of aerosol optical depth (AOD) since 2000 onboard the Terra satellite and since 2002 for the Aqua satellite. In this paper we use MODIS AOD retrieved at $550 \mathrm{~nm}$ over the oceans from the Collection 5 algorithm. Remer et al. (2008) has evaluated the
MODIS collection 5 aerosol products finding that the Aqua AOD measurements over oceans display the expected accuracy $(0.03+0.05 \mathrm{AOD})$, but that Terra AOD over the global oceans is 0.015 higher than Aqua. Thus in this analysis, we will use MODIS AOD from Aqua, although the comparison to Terra yields similar results.

The MODIS aerosol products provide a measure of particle size in the fine mode fraction (FMF). The fine AOD, calculated using AOD $\times$ FMF, is the AOD attributed to accumulation mode particles, while the coarse AOD $($ AOD $\times(1-$ FMF)) is attributed to coarse particles. In order to relate the observed reflectances to AOD, the MODIS algorithm uses a look-up table of precomputed reflectances corresponding to nine tropospheric aerosol model types. The assumed effective radii for accumulation mode "water soluble with humidity" are $r_{\text {eff }}=0.20-0.25 \mu \mathrm{m}\left(\sigma_{\mathrm{g}}=1.82 \mu \mathrm{m}\right)$ while for coarse mode "wet sea-salt type" $r_{\mathrm{eff}}=0.98-1.98\left(\sigma_{\mathrm{g}}=1.82 \mu \mathrm{m}\right)$ under ambient conditions (Levy et al., 2003). This compares well with our assumed SS $r_{\text {eff }}$ in GEOS-Chem (Sect. 2.2).

We use Level 3 (L3) global daily MODIS Aqua data on a $1^{\circ} \times 1^{\circ}$ grid. For comparison to GEOS-Chem the daily observations are regridded onto a $2^{\circ} \times 2.5^{\circ}$ grid. In order to calculate monthly and annual mean AOD, we only use highquality daily L3 data (confidence-weighted $\mathrm{QA}_{\text {mean }}$ products) which we weight by the number of Level 2 retrievals in each $2^{\circ} \times 2.5^{\circ}$ grid box as recommended by Remer et al. (2008) and Levy et al. (2009). In addition, we exclude observations with MODIS cloud fraction larger than $50 \%$ and with fewer than 20 pixels in each $2^{\circ} \times 2.5^{\circ}$ box. These 
procedures help minimize AOD enhancements due to cloud artifacts (Zhang et al., 2005; Zhang and Reid, 2006). These observations are compared to the daily GEOS-Chem model output (2005-2008) sampled under cloud free conditions at the Aqua satellite overpass time.

The ground-based Aerosol Robotics Network (AERONET) consists of hundreds of automatic instruments that measure AOD with a 0.01 accuracy (Holben et al., 1998; Smirnov et al., 2000). We use Level 2 Quality Assured AERONET climatological monthly mean average from sites for which at least 3 years of observations are available (http://aeronet.gsfc.nasa.gov/cgi-bin/climo_menu_v2_new). We interpolate the AERONET AOD to $550 \mathrm{~nm}$ based on a quadratic interpolation in $\log / \log$ space of the measured AOD at 440, 500, 670 and $870 \mathrm{~nm}$. We also use Level 2 AOD observations from the Maritime Aerosol Network (MAN), which is a component of AERONET (Smirnov et al., 2009). Between 2006 and 2008, these AOD measurements were collected on 17 ships of opportunity and research vessels (http://aeronet.gsfc.nasa.gov/new_web/ maritime_aerosol_network.html).

\section{Constraints from in situ measurements: PMEL cruises and ground-based sites}

\subsection{Comparison between PMEL observations and GEOS-Chem}

Table 2 summarizes the mean wind, SST, and SS observations observed during each of the 6 PMEL cruises. Mean coarse mode SS concentrations range from 5.1 to $8 \mu \mathrm{g} \mathrm{m}^{-3}$ and account for $\sim 94 \%$ of the total SS mass concentrations. Figure 3 compares the observed coarse mode SS to the GEOS-Chem model $\left(r_{\mathrm{d}}=0.3-3 \mu \mathrm{m}\right)$ sampled along the cruise tracks. Also shown are observed and modeled wind speeds, as well as observed SST. We first examine the cruises with the highest observed wind speeds (RITS93, ACE1, and ICEALOT) in Fig. 3a. During these cruises winds often exceeded $10 \mathrm{~m} \mathrm{~s}^{-1}$ for prolonged periods $(24-72 \mathrm{~h}$ ) when the ship encountered frontal passages at mid- and high-latitudes in both the northern and southern hemisphere (Quinn et al., 1996; Hainsworth et al., 1998).

The standard model (MODEL-STD, in red) systematically overestimates the observed coarse mode SS concentrations by factors of 2-3 under these high wind conditions poleward of $40^{\circ}$. For RITS93, the model is too high by a factor of $\sim 3$ on julian days 82-97 as the ship was sailing in the Roaring Forties, and then again on days 121-125 when the ship sailed in the N. Pacific mid-latitude westerlies (Fig. 3a). For ACE1, the model overestimates measured SS by a factor of 2 under the high winds observed after day 321 , when the ship was south of Australia. Under the North Atlantic stormy conditions sampled during ICEALOT, the model was also systematically too high (days 89-90, 92-94, 106, 109). In con- trast, the model tends to underestimate observed SS in the tropics and subtropics when winds of intermediate intensity $\left(8-15 \mathrm{~m} \mathrm{~s}^{-1}\right)$ were encountered in the central Pacific during RITS93 (days 101-102 and 111-113) and ACE-1 (days 292296, Fig. 3a). Similar model underestimates of observed SS concentrations can be seen for AEROINDO99 in the Tropical Atlantic for days 25-28 and in the Tropical Indian Ocean for days 67-82 (Fig. 3b). For ACE-Asia and VOCALS, disagreement with observations is not as pronounced as for the other cruises.

The comparison between modeled and observed SS for all cruises is summarized in Table 3 and Fig. 4b. Overall, for coarse mode SS MODEL-STD displays a mean normalized bias of $+64 \%$ (mean normalized gross error of $120 \%$ ) with a correlation coefficient of 0.55 . The correlation coefficients for individual cruises range from 0.35 to 0.78 (Fig. 3). Only half of the model points lie within a factor of 2 of observations (dashed lines in Fig. 4b). For accumulation mode SS, the model is in reasonable agreement with observations, with a mean normalized bias of $+7 \%$ and a correlation coefficient of 0.62 (Table 3).

As shown in Fig. 4a, the model meteorological fields generally capture the observed $u_{10 \mathrm{~m}}$ quite well (model/obs $=0.99, r=0.84$ ). For this figure, we have averaged $u_{10 \mathrm{~m}}$ over the aerosol sampling time. We note that the model tends to underestimate observed $u_{10 \mathrm{~m}}$ under low wind conditions $\left(<6 \mathrm{~m} \mathrm{~s}^{-1}\right)$. This could be due to smallscale variations in wind speed that are not captured by the model. For intermediate and large winds $\left(>6 \mathrm{~m} \mathrm{~s}^{-1}\right)$ where SS emissions become important, modeled $u_{10 \mathrm{~m}}$ is nearly always within $25 \%$ of observations. If we focus only on winds faster than $6 \mathrm{~m} \mathrm{~s}^{-1}$, the GEOS-5 winds (used in the VOCALS and ICEALOT simulations) show less bias and better correlation with observations (model/obs $=1.02, r=0.91$ ) than the GEOS-4 winds (model/obs $=1.08, r=0.74$ ), consistent with our earlier findings (Sect. 2.3).

We further examine the model bias for coarse mode SS by excluding observations affected by rain. This greatly reduces the number of available points (from 383 to 134) but does not change the level of disagreement. The bias also persists if we only consider observations affected by rain during the sampling period. We use this to argue that model errors in the representation of wet or dry deposition cannot explain the poor model performance. Dry deposition dominates the loss of coarse mode SS and considerable uncertainty remains on the calculation of $v_{\mathrm{d}}$. Lewis and Schwartz (2004, p. 277-283) assess different model formulations for $v_{\mathrm{d}}$, finding that they generally agree to within a factor of 2 . This is a smaller range of uncertainty than that associated with SS emissions (factor of 4). In the rest of this paper we thus focus on potential biases associated with the SS source function, its wind speed dependence and its dependence on other variables.

We examine the wind speed dependence of observed and modeled coarse mode SS in Fig. 5a. The observations display $\mathrm{a} \sim u_{10 \mathrm{~m}}^{0.7}$ dependence, with a correlation coefficient $r=0.5$. 
Table 3. Comparison between SS mass observed concentrations and model simulations.

\begin{tabular}{lrrr}
\hline Model & $\begin{array}{r}\text { Mean normalized } \\
\text { bias }^{1}\end{array}$ & $\begin{array}{r}\text { Mean normalized } \\
\text { gross error }\end{array}$ & $\begin{array}{r}\text { Correlation } \\
\text { coefficient, } r\end{array}$ \\
\cline { 2 - 4 } MODEL-STD & \multicolumn{2}{c}{ PMEL Coarse mode SS (383 points) } & \\
MODEL-U2 & $+64 \%$ & $120 \%$ & 0.55 \\
MODEL-SST & $+120 \%$ & $159 \%$ & 0.54 \\
& $+33 \%$ & $77 \%$ & 0.71 \\
MODEL-STD & PMEL Accumulation mode SS (375 points) & \\
MODEL-U2 & $+7 \%$ & $75 \%$ & 0.62 \\
MODEL-SST & $+17 \%$ & $76 \%$ & 0.57 \\
& $+6 \%$ & $73 \%$ & 0.52 \\
MODEL-STD & University of Miami monthly total SS at 15 sites (180 points) \\
\cline { 2 - 4 } MODEL-U2 & $+32 \%$ & $88 \%$ & \\
MODEL-SST & $+20 \%$ & $64 \%$ & \\
\hline
\end{tabular}

1 The mean normalized bias is defined as mean ((model-obs $) /$ obs $) \times 100 \%$.

2 The mean normalized gross error is defined as mean(abs(model-obs)/obs) $\times 100 \%$.

${ }^{3}$ For the PMEL cruises we only use open ocean points, defined as measurements taken in model grid-boxes where the ocean accounts for at least $70 \%$ of the surface area. This eliminates $\sim 5 \%$ of observations.

Thus only $25 \%$ of the variance in observations is due to wind speed, in agreement with the low correlations found in previous studies (e.g., O'Dowd et al., 1997; Gong et al., 1997b; Bates et al., 1998; Quinn and Coffman, 1999; Kleefeld et al., 2002; Shinozuka et al., 2004). The remaining variance could be due to variability in relative humidity, wet and dry deposition, advection, vertical mixing, and wind fetch integrated over the lifetime of SS. In theory, the model takes into account these other factors, yet modeled SS concentrations display a stronger wind speed dependence $\left(\sim u_{1} 0 \mathrm{~m}^{1.5}\right.$, $r=0.74$ ) than observed. We will first explore the possibility that the assumed SS source function (Eq. 1) has too strong a dependence on $u_{10 \mathrm{~m}}$.

\subsection{Dependence of sea salt emissions on $u_{10 \mathrm{~m}}$}

We use the GEOS-Chem model to calculate the mean residence time $\left(\tau_{\mathrm{SS}}\right)$ of coarse mode SS $\left(r_{\mathrm{d}}=0.3-3 \mu \mathrm{m}\right)$ in the surface layer with respect to wet and dry deposition. We find that over the PMEL cruise tracks $\tau_{\mathrm{SS}}=6 \mathrm{~h}$, with dry deposition accounting for $\sim 70 \%$ of total deposition, consistent with previous estimates (e.g. Gong et al., 1997a; Lewis and Schwartz, 2004). Given this short lifetime, we can assume local mass balance for coarse mode SS, meaning that at the time and location of measurements, SS emission and loss are equal. This yields a linear relationship between $E$ (sea salt emissions, $\mu \mathrm{g} \mathrm{m}^{-2} \mathrm{~d}^{-1}$ ) and $C$ (surface sea salt mass concentrations, $\mu \mathrm{g} \mathrm{m}^{-3}$ ): $E=\alpha \times C$, with the linear coefficient $\alpha$ depending on $\tau_{\mathrm{SS}}$ and the depth of the surface layer $\left(z_{\mathrm{SL}}\right): \alpha=z_{\mathrm{SL}} / \tau_{\mathrm{SS}}$. In practice, we calculate $\alpha$ with the GEOS-Chem model as $\alpha=E_{\text {model }} / C_{\text {model }}$. Thus we can use the model to infer coarse mode SS emissions ( $\left.E_{\text {obs }}\right)$ from observed concentrations $\left(C_{\text {obs }}\right)$ through:

$E_{\mathrm{obs}}=\frac{E_{\text {model }}}{C_{\text {model }}} \times C_{\text {obs }}$.

In the above equation we neglect horizontal advection as the mean travel time $\left(u_{10 \mathrm{~m}} \times \tau_{\mathrm{SS}}\right)$ for SS is $\sim 120 \mathrm{~km}$, which is relatively short. At very high wind speeds $\left(>15 \mathrm{~m} \mathrm{~s}^{-1}\right)$ the travel time decreases to $\sim 100 \mathrm{~km}$ because of the wind speed dependence of dry deposition. Our approach in deriving Eq. (2) is similar to the steady-state dry deposition method that has been used by many investigators to derive SS production flux from size-dependent concentration measurements (see review by Lewis and Schwartz, 2004, p. 101$105)$, but here we use both wet and dry deposition.

The resulting $E_{\mathrm{obs}}$ is evaluated at each point and is shown as a function of $u_{10 \mathrm{~m}}$ in Fig. 5b. $E_{\text {obs }}$ and $E_{\text {model }}$ are in overall agreement for $u_{10 \mathrm{~m}}$ below $10 \mathrm{~m} \mathrm{~s}^{-1}$, but above that threshold they diverge markedly with $E_{\text {obs }}$ being lower than $E_{\text {model }}$. Applying a least-squares fitting, we find that $E_{\text {obs }}$ displays a quadratic wind speed dependence $\left(u_{10 \mathrm{~m}}^{2.07}\right)$ instead of $u_{10 \mathrm{~m}}^{3.41}$ assumed in $E_{\text {model }}$.

Based on Fig. 5b, we modify Eq. (1) to match our empirically-derived $E_{\text {obs }}$ :

$\frac{d F}{d r_{80}}=25.5 u_{10 \mathrm{~m}}^{2.07} r_{80}^{-A}\left(1+0.057 r_{80}^{3.45}\right) \times 10^{1.607 e^{-B^{2}}}$.

We have changed both the exponent in the wind power law dependence and the constant proportionality factor. The GEOS-Chem simulation conducted with this new source function will be referred to as MODEL-U2 (Table 1), and we will examine its performance in Sect. 4.4. 

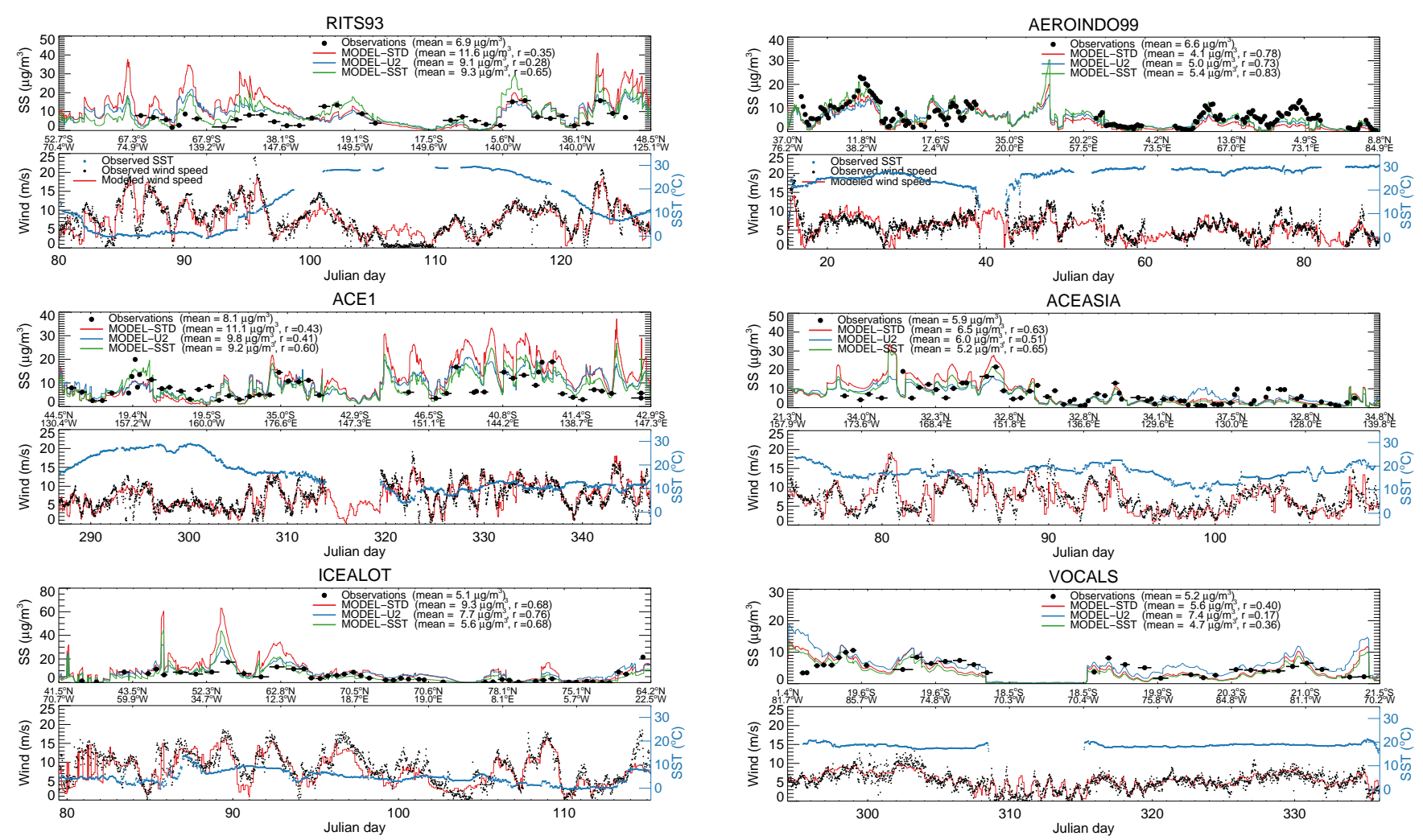

Fig. 3a. Timeseries of coarse mode SS mass concentration during the RITS93, ACE1, and ICEALOT PMEL cruises. For each cruise, observations of sea salt concentrations are shown with black circles. The horizontal bar corresponds to the instrumental averaging period. The three lines are the three different models: standard model (MODEL-STD, red), model using Eq. (3) (MODELU2, blue), model using Eq. (4) (MODEL-SST, green). The bottom panel shows the timeseries of observed $10 \mathrm{~m}$ wind speed (black dots) compared to the modeled windspeed (red line) as well as the observed SST (blue).

\subsection{Dependence of sea salt emissions on SST}

We now investigate the possibility that $E_{\text {obs }}$ depends not only on $u_{10 \mathrm{~m}}$, but also on other environmental variables, which might co-vary with $u_{10 \mathrm{~m}}$. As reviewed by Lewis and Schwartz (2004, page 266-272) a number of potential factors could affect SS emissions in addition to $u_{10 \mathrm{~m}}$, including SST, atmospheric stability, salinity, and surface-active materials. We examined the relationship between the ratio of observed to modeled SS mass concentrations $\left(C_{\text {obs }} / C_{\text {model }}\right)$ and a number of these variables for $u_{10 \mathrm{~m}}>6 \mathrm{~m} \mathrm{~s}^{-1}$. We found no dependence on observed salinity or chlorophyll concentration (as a proxy for surface-active materials).

We did however find a strong relationship between $C_{\text {obs }} / C_{\text {model }}$ and SST (Fig. 6). Figure 6 shows that the model overestimates observations for SST $<10^{\circ} \mathrm{C}$ and underestimates observations for SST $>25^{\circ} \mathrm{C}$. This confirms what we noted above when examining individual cruises:

Fig. 3b. Same as Fig. 3a but for the AERODINDO99, ACE-ASIA, and VOCALS PMEL cruises.
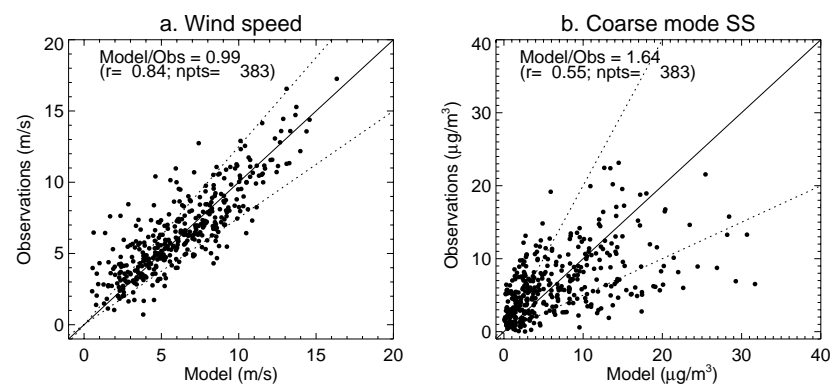

Fig. 4. Comparison between model and observations for all six PMEL cruises: (a) $10 \mathrm{~m}$ wind speed averaged over the SS sampling time; (b) coarse mode mass concentrations. The 1:1 line is shown by a solid line. The dashed lines correspond to $\pm 25 \%$ on panel (a) and to $\times / \div 2$ on panel (b). The mean model to observation ratio, correlation coefficient, and number of points are indicated on each panel figure.

the model is too high at mid- and high-latitudes (cold SST), but too low in the tropics (high SST). This is a consistent pattern across multiple cruises. The large model underestimate for SST $>25^{\circ} \mathrm{C}$ comes from observations in the Tropical Pacific (ACE1 and RITS93) as well as from the Tropical Atlantic and Indian Oceans (AEROINDO99). The model overestimate for $\mathrm{SST}<10^{\circ} \mathrm{C}$ comes from observations in 

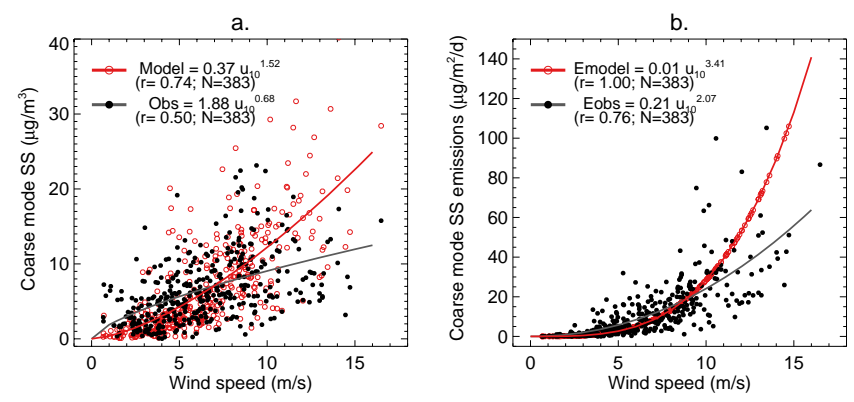

Fig. 5. Wind speed dependence of coarse mode SS concentrations (a) and emissions (b). The PMEL observations are shown with filled black circles and the standard model with open red circles. The observed SS emissions are derived using Eq. (2) (see text). The lines correspond to least-squares fitting of the model and observations to a function of the form $A \times u_{10 \mathrm{~m}}^{b}$. The values of $A$ and $b$ are indicated on the figure.

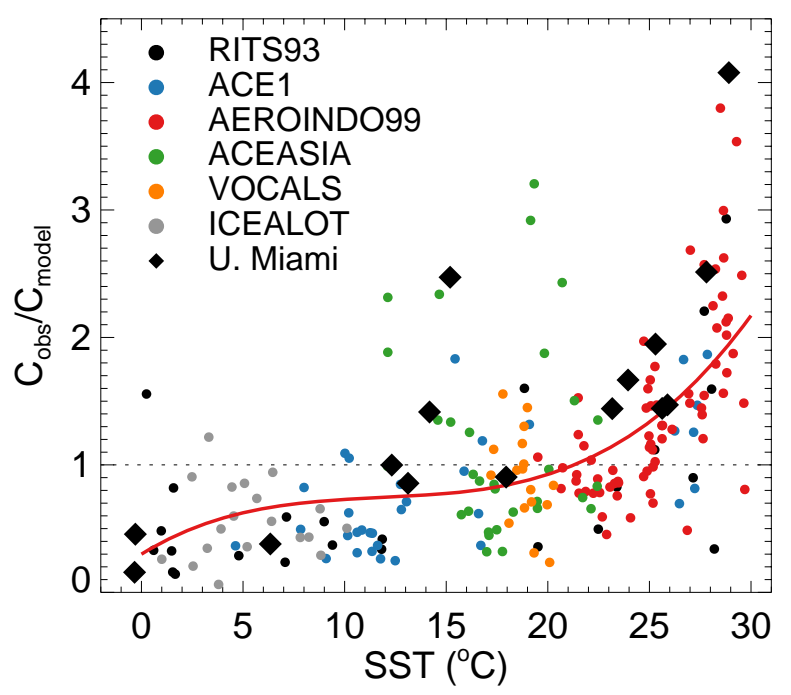

Fig. 6. Ratio of observed to modeled (MODEL-STD) mass concentrations of coarse mode SS as a function of observed sea surface temperature (SST). Each PMEL cruise is indicated by different colored circles. We only show points where $u_{10 \mathrm{~m}}>6 \mathrm{~m} \mathrm{~s}^{-1}$. The red line is the result of a least-squares fitting of the points to a 3rd order polynomial: $C_{\text {obs }} / C_{\text {model }}=0.3+0.1 \times \mathrm{SST}-0.0076 \times \mathrm{SST}^{2}+0.00021 \times \mathrm{SST}^{3}$ Also shown are the observed to modeled ratios for the 15 groundbased stations (black diamonds).

the Southern Ocean (RITS93 and ACE1), North Pacific (RITS93), and North Atlantic (ICEALOT).

Physically, there are a number of possible mechanisms by which SST could affect SS production. The kinematic viscosity of seawater has a strong dependence on temperature, decreasing by a factor of 2.2 between 0 and $30^{\circ} \mathrm{C}$ (e.g. Chen et al., 1973). As the terminal velocity of a bubble is inversely proportional to the kinematic viscosity of the surrounding fluid, bubbles in warmer waters will rise more quickly to the surface (Lewis and Schwartz, 2004, p. 250-254). This would increase the number of smaller bubbles reaching the surface in warm waters, and thus increase the production of large SS particles $\left(r_{\mathrm{d}}>0.5 \mu \mathrm{m}\right)$ by jet drops. Lower viscosity might also lead to more efficient wave breaking and a lengthened lifetime for individual whitecaps (Anguelova and Webster, 2006). In addition, the SST can affect the rate of gasexchange between the bubble and surrounding fluid and thus the number and size distribution of bubbles reaching the surface. In laboratory whitecap experiments several investigators have reported increasing production of SS with increasing water temperature for particles with $r_{\mathrm{d}}>\sim 0.5 \mu \mathrm{m}$, with factors of $\sim 2-3$ increase between $5^{\circ} \mathrm{C}$ and $25^{\circ} \mathrm{C}$ (Bowyer, 1984, 1990; Woolf et al., 1987; Mårtensson et al., 2003; Sellegri et al., 2006). Photographic whitecap measurements under a wide range of SST indicate nearly an order of magnitude increase in whitecap coverage between the coldest and warmest waters, although the large scatter in the data and the relatively few measurements under warm SSTs have prevented firm conclusions (e.g., Lewis and Schwartz (2004), p. 266-269; Anguelova and Webster (2006) and references therein). These observed SST-dependencies are thus consistent with Fig. 6, which shows a factor of 2-6 increase between $5^{\circ} \mathrm{C}$ and $30^{\circ} \mathrm{C}$.

We fit the ratio of observed to modeled concentrations (which is equal to $E_{\text {obs }} / E_{\text {model }}$ ) with a third order polynomial function indicated by the red line in Fig. 6 . We use this polynomial fit to modify the source function in Eq. (1) and derive a second empirically-based SS source function:

$$
\begin{aligned}
\frac{d F}{d r_{80}}= & \left(0.3+0.1 \times T-0.0076 \times T^{2}+0.00021 \times T^{3}\right) \\
& 1.373 u_{10 \mathrm{~m}}^{3.41} r_{80}^{-A}\left(1+0.057 r_{80}^{3.45}\right) \times 10^{1.607 e^{-B^{2}}}
\end{aligned}
$$

where $T$ is the SST expressed in ${ }^{\circ} \mathrm{C}$. For simplicity, we chose to use a single function over the entire SST range shown in Fig. 6. We note, however, that this choice leads to a conservative estimate of the SST dependence as it does not fully capture the steep rise in $C_{\mathrm{obs}} / C_{\text {model }}$ points for SST $>25^{\circ} \mathrm{C}$. The GEOS-Chem simulation conducted using Eq. (4) will be referred to as MODEL-SST (Table 1).

\subsection{Performance of new SS source functions for PMEL cruises}

We evaluate the performance of MODEL-U2 (blue line) and MODEL-SST (green line) in Fig. 3. Relative to the standard simulation, MODEL-U2 leads to a reduced bias for all individual cruises except for VOCALS where the low winds combined with Eq. (3) overestimates the observations (Fig. 3). However, using a quadratic dependence on wind speed for the source function results in a reduced variability in the predicted SS concentrations and a decrease of the correlation coefficient for individual cruises (Fig. 3). Overall, MODEL-U2 displays a worse performance than MODELSTD, with a mean normalized bias of $+120 \%$ (Table 3 ). 
MODEL-SST reduces the bias significantly and leads to an increase in the correlation between model and observations. For example, for RITS93 the model bias is reduced from $107 \%$ to $53 \%$ and the correlation coefficient increases from 0.35 to 0.65 . For AEROINDO99, the bias is reduced from $-39 \%$ to $-13 \%$ and the correlation coefficient increases from 0.78 to 0.83 . Overall, using MODEL-SST the mean normalized bias is reduced from $+64 \%$ to $+33 \%$ and the correlation coefficient increases from 0.55 to 0.71 (Table 3 ). The mean normalized gross error is reduced from $120 \%$ to $77 \%$. For accumulation mode SS, MODEL-SST yields a slight decrease in the bias (from $+7 \%$ to $+6 \%$ ) with a slightly lower correlation coefficient compared to MODEL-STD (Table 3).

In a previous study, Witek et al. (2007) found that the NAAPS model overestimated mass concentrations measured during 4 PMEL cruises: AEROINDO99, ACE-Asia, NEAQS-2002, and NEAQS-2004. The overestimate seemed to be more pronounced at high wind speeds, consistent with our results. However, when they examined how $C_{\mathrm{obs}}-$ $C_{\text {model }}$ varied as a function of SST, they did not find any trend (see their Fig. 9). When we examine $C_{\text {obs }}-C_{\text {model }}$ for AEROINDO99 and ACE-Asia (we do not include NEAQS2002 and 2004 in our analysis because these cruises took place mostly in coastal environments), we also do not find any noticeable relationship. This is because the difference between model and observations is inherently a function of wind speed (see Eq. 2), while the ratio $C_{\text {obs }} / C_{\text {model }}$ eliminates most of the wind speed influence and highlights the SST dependence. Indeed, when we plot $C_{\text {obs }} / C_{\text {model }}$ for AEROINDO99 and ACE-Asia (not shown), we do find a relationship as a function of SST, which is further enhanced by the inclusion of the other 4 open-ocean cruises spanning a larger range of SST.

\subsection{Performance of new SS source functions for ground-based observations}

We now compare the three models against independent SS observations from the University of Miami ground-based network (Fig. 7). MODEL-STD overestimates observations by factors of 2-6 at the three sites with the coldest SST: Palmer Station, King George Island, and Marion Island (sites 1-3, see locations in Fig. 1a). For the more temperate midlatitude sites (sites 4-8), MODEL-STD is generally within $10-30 \%$ of observations. One exception is Cape Grim, where MODEL-STD underestimates observations by a factor of 2. Finally, SS observations at tropical and subtropical sites (sites 9-15) are higher than MODEL-STD by factors of 1.5-4. When we examine the relationship of annual mean $C_{\text {obs }} / C_{\text {model-STD }}$ for these 15 ground sites (black diamonds in Fig. 6), we find the same overall pattern as for the PMEL cruises. We note that the points for the tropical and subtropical sites $\left(\mathrm{SST}>23^{\circ}\right)$ lie at the upper edge of the envelope of PMEL points and might indicate a contribution from local surf.
Including the SST dependence to the source function leads to improved agreement with observations. MODEL-SST displays a reduced positive bias at the coldest sites (sites 1-3), reduced negative bias at the warmest sites (sites 9-15), and similar degree of agreement at temperate sites (4-8). Overall the mean normalized bias is reduced from $+32 \%$ (MODELSTD) to $-5 \%$ (MODEL-SST), and the mean absolute bias is reduced from $88 \%$ to $40 \%$ (Table 3 ). Note the much improved agreement at King George Island (site 2), Reunion Island (site 9) and Miami (site 13). The results for MODELU2 lie between the other two model simulations.

In summary, MODEL-SST yields an improved simulation compared to MODEL-STD for PMEL cruises observations (by design as Eq. (4) was based on these observations). An independent evaluation of MODEL-SST with the U. Miami ground-based observations also yields improved agreement. MODEL-U2 does not perform as well as MODEL-SST and results in worse agreement for the PMEL cruises. Thus the hypothesis that SS emissions have a lower wind speed power law does not seem to be supported by observations. Instead, the quadratic $u_{10 \mathrm{~m}}$ dependence we found in Fig. 5 can be reproduced with MODEL-SST because the highest wind speeds were generally found over cold SSTs. In the rest of the paper we do not discuss MODEL-U2 anymore and only focus on MODEL-STD and MODEL-SST.

\section{Consistency with AOD observations}

\subsection{MODIS Aqua AOD}

The multi-year (2005-2008) annual mean ocean AOD from MODIS Aqua is compared to the GEOS-Chem AOD in Fig. 8. The model is sampled only when MODIS observations are available. In addition, we only show grid-boxes with at least 100 valid days of observations over that 4 year period. Next to the total AOD, we also show the coarse mode AOD. For the model, this corresponds to the AOD due to dust and coarse mode SS.

Both MODIS and MODEL-STD show the same general features, with enhancements in AOD downwind of anthropogenic source regions in E. Asia, India, and N. America as well as downwind of biomass burning and dust regions in Africa. We note that downwind of North Africa, the model overestimates coarse mode AOD by a factor of $\sim 2$, likely due to an overestimate of Saharan dust emissions in GEOS-Chem as discussed in Generoso et al. (2008).

Over the tropical/subtropical oceans (Pacific, South Atlantic, Indian Ocean), MODEL-STD is a factor of 2 lower than MODIS. In these remote regions, MODIS coarse mode AOD accounts for $50-70 \%$ of the AOD and dominates the spatial variability (Fig. 8). MODIS coarse mode AOD reaches up to 0.1 over the trade wind regions the Pacific and Indian Oceans. In contrast, the MODEL-STD coarse mode AOD barely reaches 0.05 in these regions where no 


\section{5-2008}
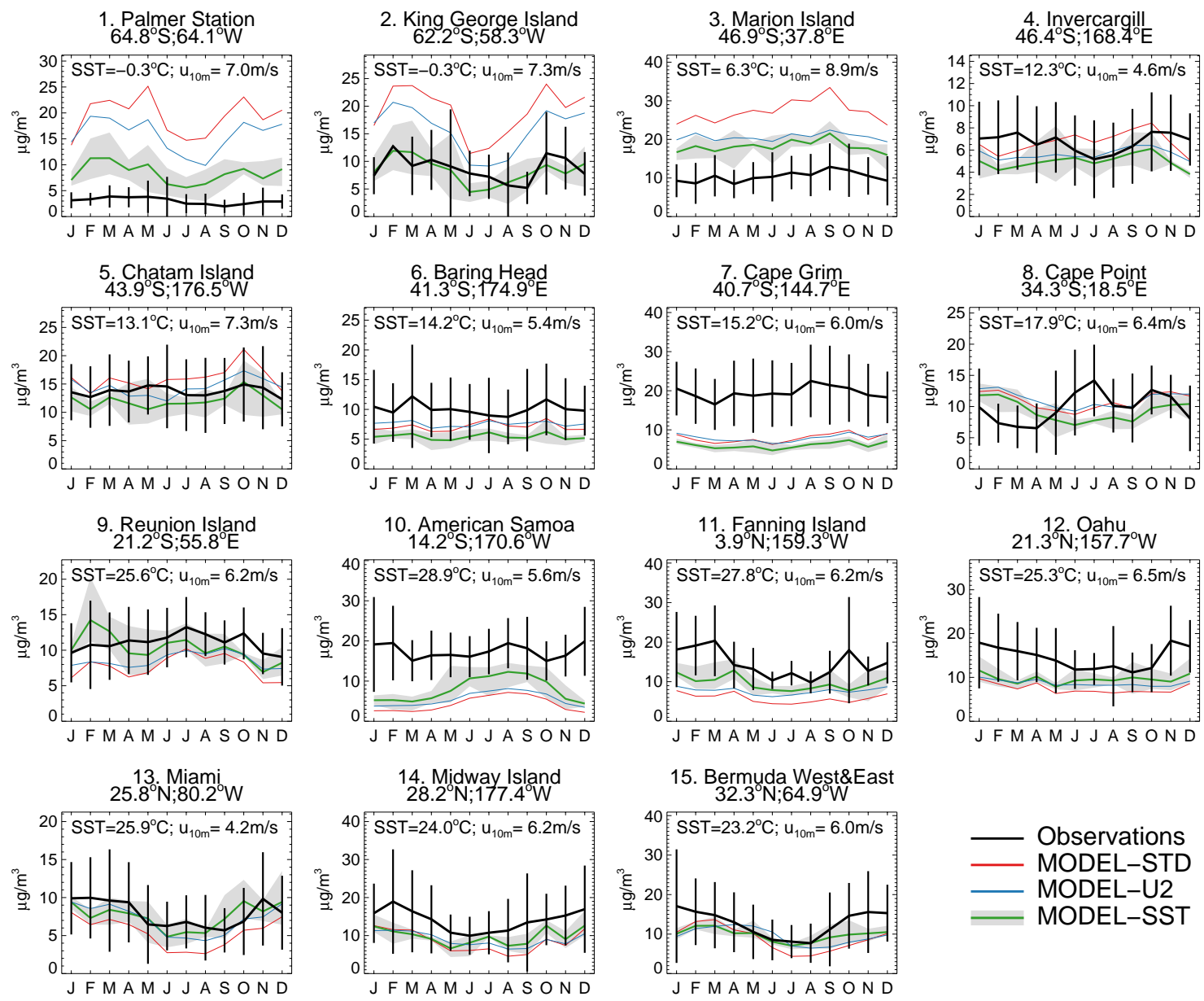

Fig. 7. SS mass concentrations measurements at $15 \mathrm{U}$. Miami ground-based stations. The locations of the stations are indicated in Fig. 1a. The observations are shown with black lines and error bars corresponding to the standard deviation of the multi-year mean. Three model simulations are shown (MODEL-STD in red, MODEL-U2 in blue, and MODEL-SST in green), with the seasonal variations calculated from 2005-2008 monthly means. For MODEL-SST the grey area indicates the interannual variability for these four years. The annual mean $u_{10} \mathrm{~m}$ and SST are listed in each panel. When the stations are located in regions surrounded by sea ice (Palmer Station and King George Island) we use the SST of the closest ice-free region.

dust is expected. The difference between MODEL-STD and MODIS (Fig. 9) is larger than the MODIS expected error $\pm(0.03+0.05$ AOD $)$. MODEL-STD overestimates MODIS AOD over the North Pacific (poleward of $40^{\circ} \mathrm{N}$ ) and over the Southern Ocean by $0.02-0.04$ (Figs. 8 and 9). Most of this overestimate is due to coarse mode AOD, which MODELSTD overestimates by $25-50 \%$.

Figure 10 shows that the ratio of MODIS to MODELSTD annual mean AOD (AOD MODIS $/$ AOD $_{\text {MODEL-STD }}$ ) has a strong SST dependence. For this figure, we only include points where $u_{10 \mathrm{~m}}>6 \mathrm{~m} \mathrm{~s}^{-1}$ and where the modeled SS contribution to the total AOD is greater than $60 \%$. The SST dependence is similar to the one we found when comparing GEOS-Chem to the PMEL cruise and ground-based observations (see red line in Fig. 10), but the MODIS points tend to fall above the PMEL fit. We will examine this issue in more detail below as we compare the model to AERONET observations (Sect. 5.2).

As shown in Figs. 8 and 9, inclusion of our SST-dependent SS source function in MODEL-SST eliminates most of the discrepancies with MODIS over both tropical and high latitude regions: over most of the global oceans the difference between MODIS and MODEL-SST is below 0.04 and often below 0.02. Over the Southern Ocean, MODEL-SST is slightly lower than MODIS.

The remaining area where MODEL-SST displays significant differences is located in the equatorial Atlantic over the Gulf of Guinea, where the model is much lower than observations. The fine mode AOD agrees well (not shown) and the discrepancy is associated with coarse mode AOD and is 


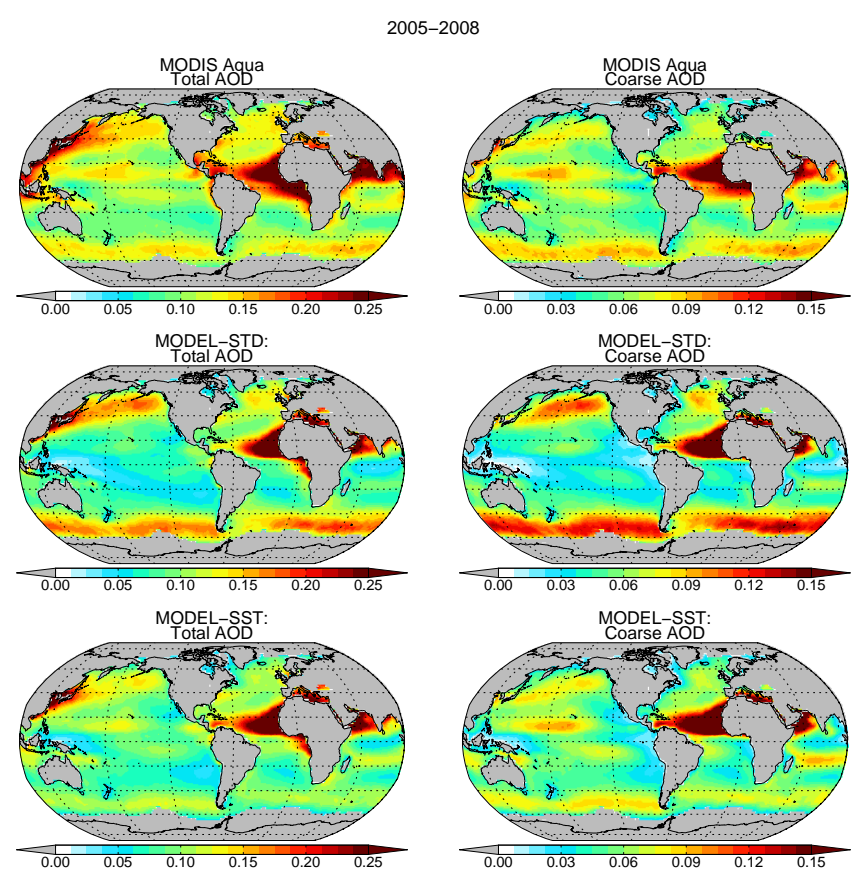

Fig. 8. Annual mean total AOD (left panels) and coarse mode AOD (right panels) at $550 \mathrm{~nm}$ over the oceans for 2005-2008. Top row: MODIS Aqua. Central row: GEOS-Chem MODEL-STD. Bottom row: MODEL-SST. The daily model AOD are sampled only on the days where MODIS AOD is available. Only grid-boxes with more than 100 days of data availability (over the 4 year period) are shown. The model coarse AOD is calculated as the sum of AOD from dust and coarse mode SS. Note the different colorbars for the left and right columns.
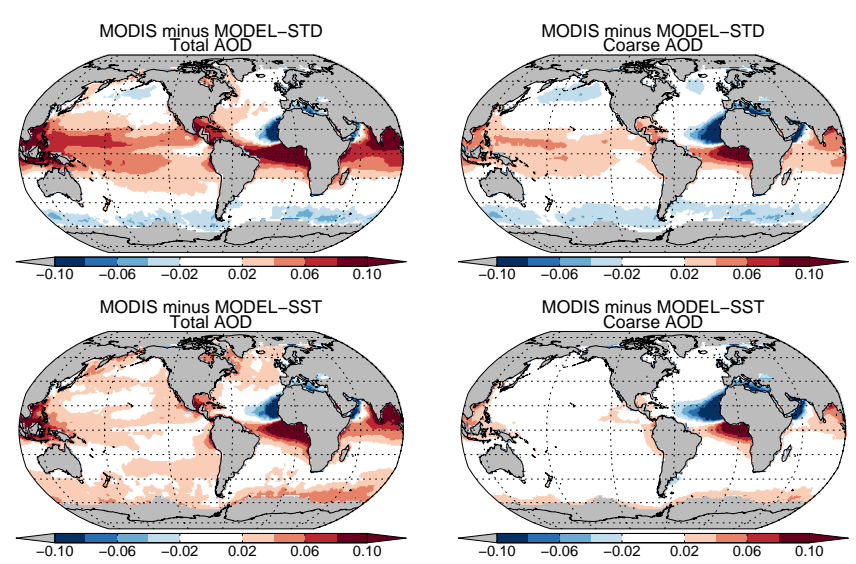

Fig. 9. Difference between annual mean MODIS Aqua and GEOSChem total AOD (left column) and coarse mode AOD (right column) for 2005-2008. Top panels: MODIS minus MODEL-STD. Bottom panels: MODIS minus MODEL-SST.

present throughout the year. This is a region with low wind speeds (3-6 $\mathrm{m} \mathrm{s}^{-1}$, Fig. 1a) and thus the model predicts very little SS. The reasons for the discrepancy are unclear, and

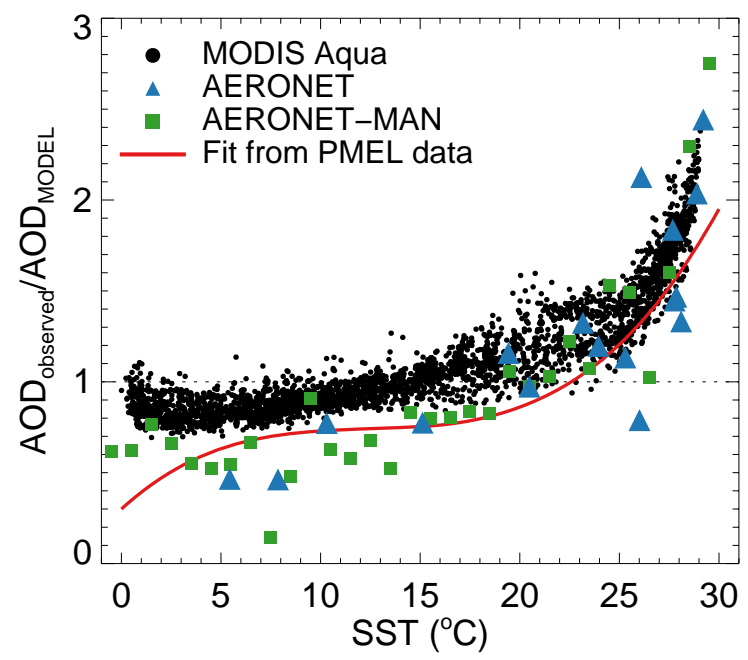

Fig. 10. SST dependence of the ratio of annual mean MODIS Aqua to MODEL-STD AOD. We only show points for regions where $u_{10 \mathrm{~m}}>6 \mathrm{~m} \mathrm{~s}^{-1}$ and modeled SS account for more than $60 \%$ of the total modeled AOD. The blue triangles correspond to the annual mean ratio of the 17 AERONET sites displayed in Fig. 11. The green squares are for the Maritime Aerosol Network (AERONETMAN) binned by SST. The red line is the polynomial fit obtained from least-squares fitting of $C_{\mathrm{obs}} / C_{\text {model }}$ in Fig. 6.

could be associated with errors in model winds in that region, or alternatively as this region near the ITCZ is particularly cloudy, the observed high AOD could be due to cloud contamination in the MODIS retrieval.

\subsection{AERONET AOD}

We select 17 AERONET stations for which GEOS-Chem predicts that SS account for at least $50 \%$ of the AOD (see location of sites in Fig. 1b). The comparison to MODEL-STD in Fig. 11 displays the same overall pattern: model AOD is too high at high- and mid-latitude sites (stations $1-4$, with $\mathrm{SST}<20^{\circ} \mathrm{C}$ ), model AOD is too low for warm tropical sites (stations $7-13, \mathrm{SST}>26^{\circ} \mathrm{C}$ ), and there is relatively good agreement for temperate sites (stations $5,14,15,16,17,20^{\circ}<\mathrm{SST}<26^{\circ} \mathrm{C}$ ). The discrepancy

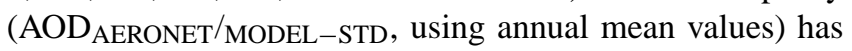
a very similar SST-dependence as the fit from the PMEL observations (Fig. 10), but generally falls below the MODIS points for $\mathrm{SST}<18^{\circ} \mathrm{C}$.

This offset between AERONET and MODIS could be caused by residual cloud contamination in MODIS, as cloud cover is particularly extensive at high latitudes with colder SSTs. Some of the bias could also be due to the assumption of a constant wind speed of $6 \mathrm{~m} \mathrm{~s}^{-1}$ in the calculation of ocean surface reflectance in the MODIS algorithm (Levy et al., 2003). Because of this assumption, the enhanced surface reflectance due to whitecaps could be attributed to 

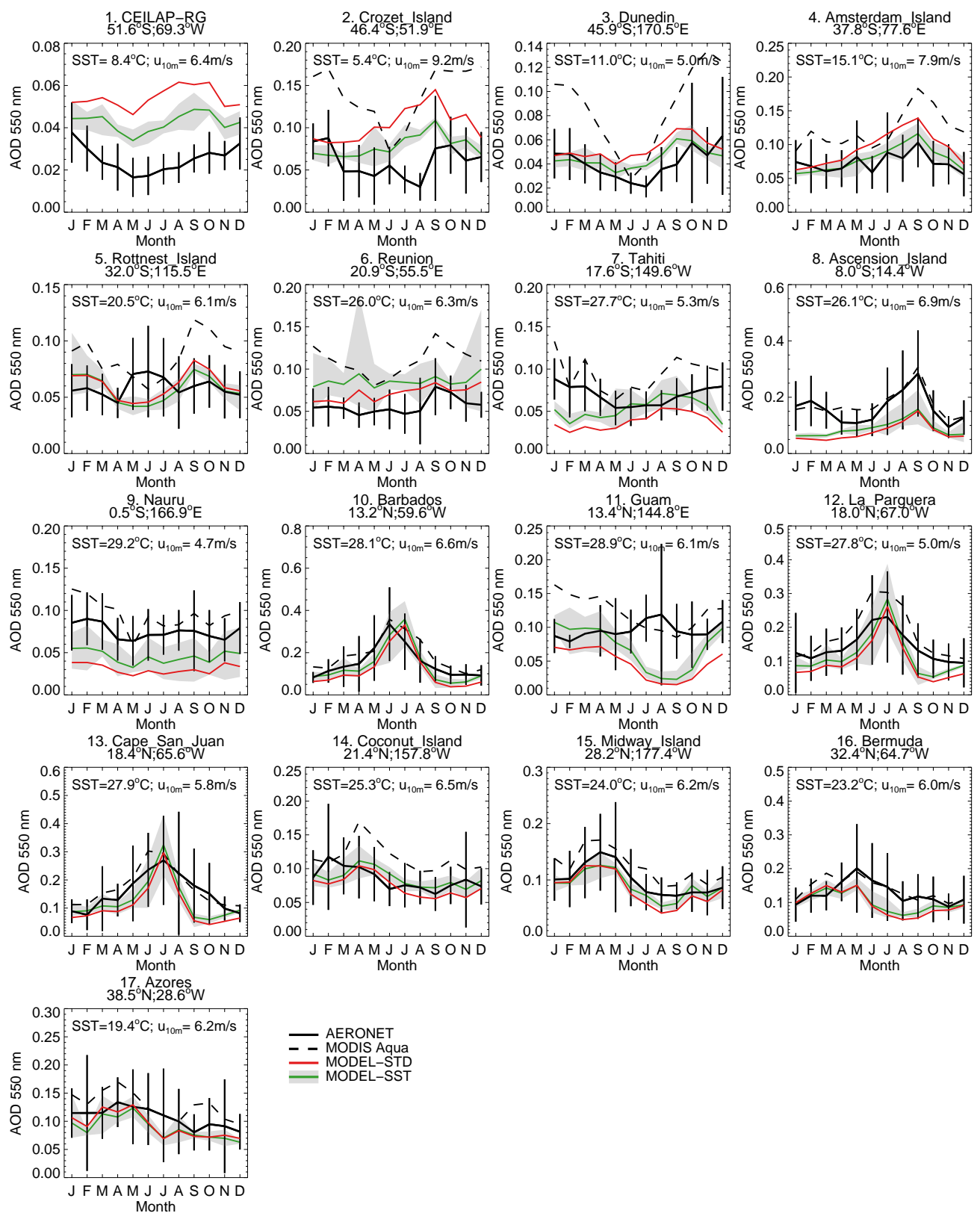

Fig. 11. Seasonaly cycle of $550 \mathrm{~nm}$ AOD at 17 AERONET sites. Only sites for which SS accounts for more than $50 \%$ of AOD are shown. AERONET observations (black line with error bars) are compared to two model simulations for 2005-2008: MODEL-STD (red) and MODEL-SST (green with grey shading indicating range of monthly means over the 4 years). Also shown is the MODIS Aqua AOD sampled at the location of each AERONET site (dashed black line).

atmospheric aerosols, thus overestimating the AOD (Zhang and Reid, 2006; Kahn et al., 2007). As ocean reflectance due to whitecaps and sun glint reflection increase with increasing wind speed and SZA, the potential errors will maximize at high latitudes. When we sample the MODIS AOD at the AERONET sites (Fig. 11), we find that MODIS is generally higher than AERONET AOD. The difference between MODIS and AERONET is largest at Crozet Island and Dunedin.

The AOD predicted by MODEL-SST is in better agreement with AERONET observations, reducing the positive bias at cold SSTs and the negative bias at warm SSTs 
(Fig. 11). One exception is Reunion Island (AERONET site 6), where MODEL-SST is higher than AERONET by 0.03 . SS concentrations predicted by MODEL-SST agrees with observations from the U. of Miami network at Reunion Island (site 9 in Fig. 6) thus the AOD overestimate likely comes from a model overestimate of sulfate aerosols. The high AOD at Nauru cannot be reproduced by MODEL-SST. However it appears that there are unusually strong surf conditions on this island leading to enhanced production of SS which can be observed for several $\mathrm{km}$ downwind (Henderson et al., 2006). As the AERONET site is located on the western side of Nauru, surf zone SS could be transported to that location by the dominant easterly winds. At Guam MODEL-SST underestimates AERONET AOD between July and October, when winds are at a minimum. The reasons for this underestimate are unclear.

We also examine shipboard AOD observations collected as part of the Maritime Aerosol Network (AERONET-MAN), which is a component of AERONET. MODEL-STD was sampled at the locations and dates corresponding to the AERONET-MAN observations. We select a subset of observations for which $u_{10 \mathrm{~m}}>6 \mathrm{~m} \mathrm{~s}^{-1}$ and GEOS-Chem predicts that SS account for at least $50 \%$ of the AOD. Figure 10 shows

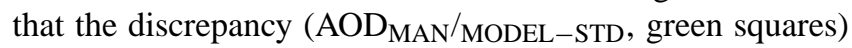
for this subset of observations displays a SST-dependence similar to the ground-based AERONET measurements and to the fit from PMEL observations. The AERONET-MAN points at cold $\mathrm{SST}\left(<5^{\circ} \mathrm{C}\right)$ correspond to measurements obtained over the Southern Ocean $\left(50^{\circ} \mathrm{S}-70^{\circ} \mathrm{S}\right)$, while the warm SST measurements were obtained during cruises over the tropical Atlantic, Pacific, and Indian Oceans.

In summary, AOD observations from MODIS and AERONET confirm our finding of a SST-dependent SS production. The global coverage afforded by MODIS demonstrates the large-scale enhancements in AOD in the tropics. MODEL-SST reproduces most of this tropical/subtropical enhancement in AOD, which we attribute to SS aerosols produced efficiently under warm SST conditions.

The discrepancy between models and satellite observations over the tropical/subtropical Pacific ocean has been a long-standing problem common to many different models and satellite products. Penner et al. (2002) noted that in the $10^{\circ} \mathrm{N}-30^{\circ} \mathrm{S}$ region models were systematically lower than AOD retrieved from AVHRR by an average of 0.06 . In an AeroCom model intercomparison study, Kinne et al. (2006) found that the median AOD predicted by 16 participating models was too low over the tropical oceans compared to retrievals from multiple satellites (MODIS, AVHRR, POLDER, TOMS, MISR). This issue remained unresolved because comparison with the few AERONET sites in the region was inconclusive (Chin et al., 2004; Kinne et al., 2006; Lee and Adams, 2010). Penner et al. (2002) attempted to reproduce the high AODs observed over the tropical oceans by increasing DMS and sea salt fluxes globally. They found that while this improved agreement in the trop- ics, it lead to a model overestimate at high latitudes. Our study demonstrates that a SS source function dependent on both windspeed and SST can resolve this long-standing underestimate of models in reproducing the high AOD in the tropics/subtropics without leading to an overestimate at high latitudes.

\section{New sea salt budget}

We compare the new SS budget (MODEL-SST) to the standard model simulation (MODEL-STD) in Table 4 for the year 2008. Global SS emissions in MODEL-SST, $4600 \mathrm{Tg} \mathrm{yr}^{-1}$, are $12 \%$ lower than MODEL-STD. We find that $50 \%$ of the emissions are for SS with dry radius $r_{\mathrm{d}}>$ $4 \mu \mathrm{m}$, while $49 \%$ with $0.5<r_{\mathrm{d}}<4 \mu \mathrm{m}$ and the remaining $1 \%$ in accumulation mode SS $\left(r_{\mathrm{d}}<0.5 \mu \mathrm{m}\right)$. The new mean global burden of SS is $8.5 \mathrm{mg} \mathrm{m}^{-2}$ in MODEL-SST, $6 \%$ lower than MODEL-STD. In both simulations, the burden is dominated by SS with $0.5<r_{\mathrm{d}}<4 \mu \mathrm{m}$ (accounting for $70 \%$ of the burden), followed by SS with $r_{\mathrm{d}}>4 \mu \mathrm{m}$ (25\% of burden) and accumulation mode SS (5\%). The loss of accumulation mode SS is dominated by wet deposition, with an overall lifetime of $25 \mathrm{~h}$. For $0.5<r_{\mathrm{d}}<4 \mu \mathrm{m}$ particles size, the lifetime is $12 \mathrm{~h}$ with loss equally distributed between wet and dry deposition. The lifetime of the larger particle bin decreases to $4 \mathrm{~h}$ and is dominated by dry deposition (Table 4 ).

Our mean global burdens for both simulations are within the range calculated in previous studies ( 4.5 to $25 \mathrm{mg} \mathrm{m}^{-2}$ ) with most studies clustering around $\sim 10-15 \mathrm{mg} \mathrm{m}^{-2}$ (Takemura et al., 2000; Grini et al., 2002; Liao et al., 2004; Alexander et al., 2005; Textor et al., 2006; Ma et al., 2008). Our emissions are also consistent with past work, and match the best estimate global SS source of $5000 \mathrm{Tg} \mathrm{yr}^{-1}$ of Lewis and Schwartz (2004).

The spatial distribution of SS emissions, burden, and surface concentrations shows a large geographical shift between MODEL-STD and MODEL-SST (Fig. 12). Emissions decrease by $35-70 \%$ for latitudes poleward of $40^{\circ}$, and increase by $60 \%$ on average between $20^{\circ} \mathrm{S}$ and $20^{\circ} \mathrm{N}$ (Fig. 12a, b, and c). As a result, the SS burden increases by $50 \%$ in the tropics and decreases by $40 \%$ at high latitudes. The new distribution of SS in MODEL-SST is more uniform with latitude (Fig. 12, panels $\mathrm{f}$ and $\mathrm{i})$, with nearly equal burdens in the trade winds $\left(\sim 14 \mathrm{mg} \mathrm{m}^{-2}\right)$ as in the Southern Ocean $\left(\sim 16 \mathrm{mg} \mathrm{m}^{-2}\right)$. In contrast, for MODEL-STD the zonally averaged burden over the Southern Ocean $\left(\sim 28 \mathrm{mg} \mathrm{m}^{-2}\right)$ was nearly three times larger than over the tropical oceans.

Because of the wind speed dependence of dry deposition, the lifetime of coarse mode SS is longer in tropical regions ( $\sim 15 \mathrm{~h}$ for the $0.5-4 \mu \mathrm{m}$ size bin) relative to high-latitudes ( $\sim 9 \mathrm{~h})$. The lower $\mathrm{RH}$ in the subtropics accentuates this by resulting in lower size-dependent dry deposition fluxes. Thus the shift in SS emissions from high latitudes to tropical regions in MODEL-SST leads to a slight increase in the global 
Table 4. SS budgets for the standard model (MODEL-STD) and for the model with the SST dependent source function (MODEL-SST) for the year 2008 .

\begin{tabular}{lrrrr|rrrr}
\hline & \multicolumn{4}{c|}{ MODEL-STD } & \multicolumn{4}{c}{ MODEL-SST } \\
\cline { 2 - 9 } & $0.01-0.5 \mu \mathrm{m}^{*}$ & $0.5-4 \mu \mathrm{m}$ & $4-10 \mu \mathrm{m}$ & Total & $0.01-0.5 \mu \mathrm{m}$ & $0.5-4 \mu \mathrm{m}$ & $4-10 \mu \mathrm{m}$ & Total \\
\hline Emissions (Tg yr ${ }^{-1}$ ) & 67 & 2533 & 2600 & 5200 & 59 & 2241 & 2300 & 4600 \\
Dry deposition $\left(\mathrm{Tg} \mathrm{yr}^{-1}\right.$ ) & 4 & 1306 & 2040 & 3350 & 3 & 1030 & 1717 & 2750 \\
Wet deposition $\left(\mathrm{Tg} \mathrm{yr}^{-1}\right.$ ) & 63 & 1227 & 560 & 1850 & 56 & 1211 & 583 & 1850 \\
Lifetime (days) & 1.09 & 0.47 & 0.17 & 0.33 & 1.03 & 0.5 & 0.19 & 0.35 \\
Burden $\left(\mathrm{mg} \mathrm{m}^{-2}\right.$ ) & 0.4 & 6.4 & 2.3 & 9.1 & 0.3 & 5.9 & 2.3 & 8.5 \\
\hline
\end{tabular}

* All model size bins are given in dry particle radius, $r_{\mathrm{d}}$.

mean lifetime of the coarse mode SS and a slight decrease of accumulation mode SS lifetime (wet deposition is stronger in the tropics), as shown in Table 4.

\section{Discussion}

We found a clear SST dependence of coarse mode SS emissions across multiple datasets, in addition to the well-known wind speed dependence. As discussed in Sect. 4.3, there is a physical basis for this via the strong decrease in viscosity with increasing temperatures, affecting rise speed of bubbles as well as bubble size distributions. It is also possible that other environmental factors co-varying with SST could be causing or enhancing the dependence we observed. For example the trade winds tend to persist over long times and the large fetch might lead to enhanced SS production over their warmer waters. In contrast, mid-latitude westerlies are much more variable and could lead to reduced SS emissions for the same mean wind speed. Furthermore, warmer waters in the subtropical gyres are often nutrient poor, while the colder surface ocean waters at high latitudes are generally regions of upwelling and thus more productive. Enhanced productivity could lead to the presence of surface-active materials, which might change the properties of rising bubbles and their production of film and jet drops (Sellegri et al., 2006; Tyree et al., 2007; Fuentes et al., 2010).

Could it be that the strong SST-dependence that we found (Figs. 6 and 10) is an artifact resulting from systematic errors in meteorological fields as a function of latitude? We have already examined potential errors in model wind speeds, finding no systematic bias compared to cruise observations, NCEP reanalyses, and QuikSCAT observations (Sects. 2.3 and 4.1). Errors in RH could lead to incorrect prediction of SS growth affecting loss by dry deposition and AOD calculation. We compared the GEOS-5 RH to surface marine observations from the Comprehensive Ocean-Atmosphere Data Set (ICOADS: http//icoads.noaa.gov) finding generally good agreement (mean normalized model bias of $+2.6 \%$ for annual mean RH).
Two independent studies support the new spatial distribution of SS displayed in Fig. 12. Anguelova and Webster (2006) have presented the first global whitecap coverage distribution based on satellite measurements of brightness temperature of the sea surface. They find that whitecaps cover $3.05 \%$ of the ocean's surface, consistent with previous results. However, compared to the commonly used Monahan and O'Muircheartaigh (1980) whitecap formula, the satellite-derived whitecaps show a strikingly different spatial distribution: more uniform latitudinally with enhanced whitecaps in the trade wind regions and weaker whitecaps at high latitudes (see their Fig. 5). Haywood et al. (1999) compared ERBE observations of clear-sky reflected solar irradiance with GCM calculations. When the GCM included all aerosols except SS, they found a fairly uniform deficit in predicted reflectance over the tropical and southern hemisphere oceans (their Fig. 1b). In order to reproduce the high top of the atmosphere reflectance in the tropics they had to invoke a very large SS burden, $36.8 \mathrm{mg} \mathrm{m}^{-2}$. However this lead to an overestimate in the mid- and high-latitude $\mathrm{NH}$ oceans.

While our finding of a SST-dependence to SS emissions is robust, the actual parameters in Eq. (4) are likely to be model dependent to some degree as our approach in deriving these parameters was to fit the model bias relative to PMEL observations. If the same analysis were to be carried out with a different model using different meteorological fields, dry deposition scheme, or boundary layer mixing scheme, then the parameters might be somewhat different. We note that Tsigaridis et al. (2010) recently implemented our SST parameterization in the GISS model, finding improved agreement with SS observations compared to a number of other parameterizations they examined.

In this study we focused on coarse mode SS which accounts for $>90 \%$ of observed SS mass (Sect. 4.1). However, accumulation mode SS dominate the number distribution and play an important role as a CCN. We did not emphasize the accumulation mode PMEL measurements in this work because the analysis is complicated by their longer lifetime ( $\sim 1$ day) and the dominant role of wet deposition in their loss (Table 4). Based on measurements of laboratory-generated 

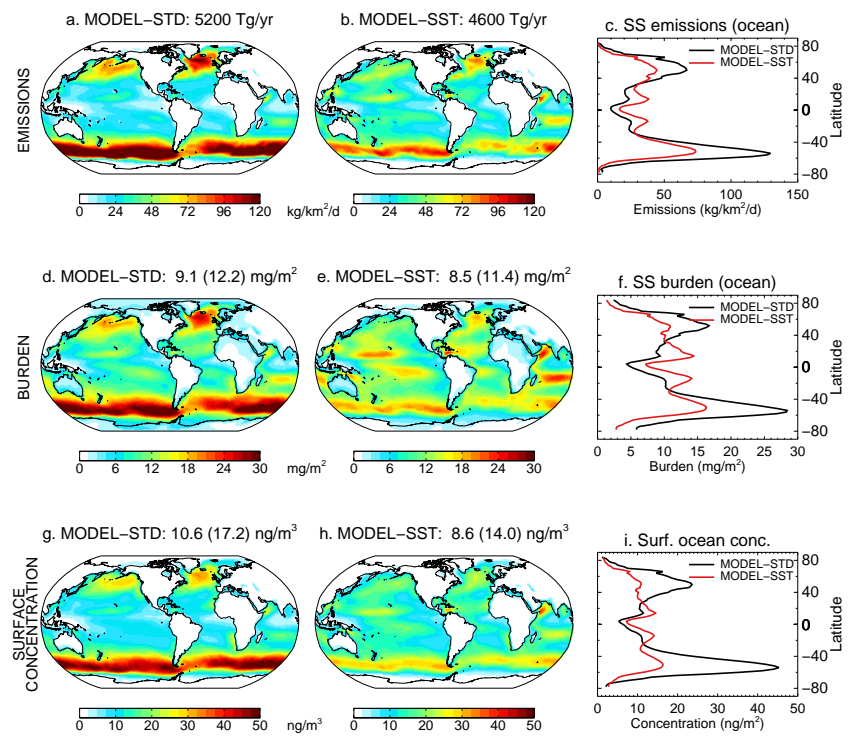

Fig. 12. Comparison of the GEOS-Chem 2008 SS emissions (top row), burden (middle row), and surface concentrations (bottom row) for MODEL-STD (left panels: a, d, g) and MODEL-SST (central panels: b, e, h). The righ column show a zonal average of over ocean SS emissions, burden, and surface concentrations. The global mean values are indicated on the first two columns, with global mean over ocean values in parenthesis.

bubbles, Mårtenssen et al. (2003) found that increasing water temperature results in a complex behavior of submicron $\mathrm{SS}$, with increasing SS production for $r_{\mathrm{d}}>0.175 \mu \mathrm{m}$ and decreasing production for $r_{\mathrm{d}}<0.035 \mu \mathrm{m}$. In a sensitivity study using the Mårtensson et al. (2003) parameterization in GEOS-Chem (see Supplement), we find that PMEL accumulation mode SS mass concentrations are overpredicted with a mean normalized bias of $80 \%(r=0.48)$. One potential issue with laboratory generation of SS by bubbling water through porous media is that it might not accurately reproduce bubble formation via wave breaking in the open ocean (Fuentes et al., 2010).

\section{Summary and implications}

In this paper we have re-evaluated the global emissions and concentrations of SS in the marine atmosphere using openocean measurements of SS mass concentrations from six PMEL cruises which sampled all the main ocean basins from $80^{\circ} \mathrm{N}$ to $70^{\circ} \mathrm{S}$ between 1993 and 2008. We compared coarse mode SS observations to the GEOS-Chem SS simulation using the wind speed-only SS source function of Gong (2003), based on the commonly-used Monahan et al. (1986) scheme. We found that the model overestimates observations under high wind conditions of mid- and high-latitudes, but underestimates observations at intermediate wind speeds in the tropics and subtropics. This pattern was confirmed by comparison to mass concentration measurements obtained at 15 ground-based stations.

We first examined the possibility that the source function has a lower power law dependence on wind speed (quadratic instead of cubic). However, observations did not support this hypothesis, as it leads to larger model biases and lower correlation coefficients.

We found that the discrepancy between model and observations is a strong function of SST. Based on the cruise measurements, we have added a SST-dependence to the Gong (2003) source function. This new empirical source function reduces the model bias by nearly a factor of two for both cruise and station observations. The resulting modeled SS mass concentrations are reduced by a factor of $\sim 2$ at high latitudes and increased by 50\% in the tropics.

Our empirically-derived SS source function yields a picture of relatively uniform distribution of SS mass concentrations in the marine boundary layer, consistent with cruise observations as well as ground-based station measurements. This is in contrast with the standard view of SS spatial distribution, which is dominated by high concentrations at high latitudes, with much lower concentrations in the tropics. Our SST- and wind speed-dependent source function leads to lower AOD over the North Atlantic, North Pacific and Southern Oceans and higher AOD (with values near 0.1) over remote tropical regions, consistent with observations from MODIS Aqua and AERONET. Enhanced SS production over tropical waters thus provides a solution for the long-standing issue of systematic model underestimates of AOD and top of the atmosphere reflectance in the tropics.

These results have significant implications for the climate and chemistry of the marine atmosphere. Higher than previously assumed SS emissions in the tropics will lead to larger impacts of SS on the chemistry of the marine boundary layer, affecting concentrations of halogens, ozone, reactive nitrogen, mercury, and sulfur containing compounds. Current studies find a factor of 2 decrease between the clear-sky and all-sky direct radiative forcing of SS because they predict that most of the SS burden is located in the cloudy mid- and highlatitudes (Winter and Chylek, 1997; Grini et al., 2002; Ma et al., 2008). Thus shifting the SS distribution to the relatively cloud-free tropics will likely enhance their overall climatic impact. It has been proposed that increasing SS emissions due to faster winds in a warmer climate might provide a significant negative climate feedback (Latham and Smith, 1990; Korhonen et al., 2010). Mahowald et al. (2006) found little sensitivity of global SS emissions in a $2 \times \mathrm{CO}_{2}$ simulation with the CCSM3 General Circulation Model (GCM), however they inferred a much higher sensitivity of SS emissions (5\% to $48 \%$ increase) in other GCMs in future climate projections. Tropical SSTs have increased by $0.3-1{ }^{\circ} \mathrm{C}$ between 1870-1900 and 2001-2005, with the largest warming found in the western Pacific Ocean and in the Indian Ocean (Hansen et al., 2006). Climate model calculations for 2100 
predict a $2-4{ }^{\circ} \mathrm{C}$ increase in surface air temperature (and thus SST) over the tropical/subtropical oceans and weaker increases $\left(0.5-2{ }^{\circ} \mathrm{C}\right)$ over the Southern Ocean and North Atlantic (Meehl et al., 2007). Based on Eq. (4), we derive an average of $7 \%$ increase in SS emissions per $1{ }^{\circ} \mathrm{C}$ increment. This sensitivity is larger at warmer SSTs $\left(+10 \% /{ }^{\circ} \mathrm{C}\right.$ for $\left.\mathrm{SST}>25^{\circ} \mathrm{C}\right)$ and colder SSTs $\left(+16 \% /{ }^{\circ} \mathrm{C}\right.$ for SST $\left.<5^{\circ} \mathrm{C}\right)$. Thus this SST-dependence could lead to an enhanced negative feedback on climate.

Field measurements specifically targeted at determining the SST dependence of SS emissions under a range of conditions would be extremely valuable. Our work suggests a very strong SST dependence at warm temperatures (25$\left.30^{\circ} \mathrm{C}\right)$ and cold temperatures $\left(0-10^{\circ} \mathrm{C}\right)$. More detailed in situ measurements of the size distribution of SS over the subtrop$\mathrm{ical} /$ tropical oceans, in particular in the trade wind regions of the Pacific Ocean, and at high latitudes over the Southern Ocean, would help confirm this finding. If these measurements are taken at high temporal resolution and are accompanied by detailed observations of meteorological conditions as well as surface water conditions (whitecap coverage, SST, composition of seawater) they can be extremely valuable in testing models and deriving more accurate source functions.

\section{Supplementary material related to this article is available online at: http://www.atmos-chem-phys.net/11/3137/2011/ acp-11-3137-2011-supplement.pdf.}

Acknowledgements. This work was supported by funding from the NASA Atmospheric Composition Modeling and Analysis Program under award NNX08AK49G. This paper has benefited from discussions with Tad Anderson and Rob Wood. We acknowledge the MODIS and QuikSCAT mission scientists and science teams for the production of the data used in this analysis. We thank the AERONET PIs and their staff for establishing and maintaining the sites used in this investigation.

Edited by: M. Schulz

\section{References}

Alexander, B., Park, R. J., Jacob, D. J., Li, Q. B., Yantosca, R. M., Savarino, J., Lee, C. C. W., and Thiemens, M. H.: Sulfate formation in sea-salt aerosols: Constraints from oxygen isotopes, J. Geophys. Res., 110, D10307, doi:10.1029/2004JD005659, 2005.

Andreas, E. L.: A new sea spray generation function for wind speeds up to $32 \mathrm{~m} \mathrm{~s}^{-1}$, J. Phys. Oceanogr., 28, 2175-2184, 1998.

Anguelova, M. D. and Webster, F.: Whitecap coverage from satellite measurements: A first step toward modeling the variability of oceanic whitecaps, J. Geophys. Res., 111, C03017, doi:10.1029/2005JC003158, 2006.

Bates, T. S., Kapustin, V. N., Quinn, P. K., Covert, D. S., Coffman, D. J., Mari, C., Durkee, P. A., De Bruyn, W. J., and Saltzman, E. S.: Processes controlling the distribution of aerosol particles in the lower marine boundary layer during the First Aerosol Characterization Experiment (ACE 1), J. Geophys. Res., 103, 1636916383, 1998.

Bates, T. S., Coffman, D. J., Covert, D. S., and Quinn, P. K.: Regional marine boundary layer aerosol size distributions in the Indian, Atlantic, and Pacific Oceans: A comparison of INDOEX measurements with ACE-1, ACE-2, and Aerosols99, J. Geophys. Res., 107(D19), 8026, doi:10.1029/2001JD001174, 2002.

Bentamy, A., Queffeulou, P., Quilfen, Y., and Katsaros, K.: Ocean surface wind fields estimated from satellite active and passive microwave instruments, IEEE T. Geosci. Remote, 37, 2469-2486, 1999.

Berg, O. H., Swietlicki, E., and Krejci, R.: Hygroscopic growth of aerosol particles in the marine boundary layer over the Pacific and Southern Oceans during the First Aerosol Characterization Experiment (ACE 1), J. Geophys. Res., 103(D13), 16535-16545, doi:10.1029/97JD02851, 1998.

Berner, A., Lurzer, C., Pohl, F., Preining, O., and Wagner, P.: The size distribution of the urban aerosol in Vienna, Sci. Total Environ., 13, 245-241, 1979.

Bey I., Jacob, D. J., Yantosca, R. M., Logan, J. A., Field, B., Fiore, A. M., Li, Q., Liu, H.,. Mickley, L. J., and Schultz, M.: Global modeling of tropospheric chemistry with assimilated meteorology: Model description and evaluation, J. Geophys. Res., 106, 23073-23096, 2001.

Blanchard, D. C.: The production, distribution and bacterial enrichment of the sea-salt aerosol, in: Air-Sea Exchange of Gases and Particles, edited by: Liss, P. S. and Slinn, W. G. N., Reidel, Boston, USA, 407-454, 1983.

Bowyer, P. A.: Aerosol production in the whitecap simulation tank as a function of water temperature (Appendix E), in: Whitecap an the Marine Atmosphere, Report No.7, edited by: Monahan, E. D., Spillane, M. C., Bowyer, P. A., Higgins, M. R., and Stabeno, P. J., 95-103, University College, Galway, Ireland, 1984.

Bowyer, P. A., Woolf, D. K., and Monahan, E. C.: Temperature dependence of the charge and aerosol production associated with a breaking wave in a whitecap simulations tank, J. Geophys. Res., 95, 5313-5319, 1990.

Chen, S. F., Chan, R. C., Read, S. M., and Bromley, L. A.: Viscosity of sea water solutions, Desalination, 13, 37-51, 1973.

Chin, M., Chu, A., Levy, R., Remer, L., Kofman, Y., Holben, B., Eck, T., Ginoux, P., and Gao, Q.: Aerosol distribution in the Northern Hemisphere during ACE-Asia: Results from global model, satellite observations, and Sun photometer measurements, J. Geophys. Res., 109, D23S90, doi:10.1029/2004JD04829, 2004.

Clarke, A. D., Owens, S. R., and Zhou, J. C.: An ultrafine sea-salt flux from breaking waves: Implications for cloud condensation nuclei in the remote marine atmosphere, J. Geophys. Res., 111, D06202, doi:10.1029/2005JD006565, 2006.

de Leeuw, G., Neele, F. P., Hill, M., Smith, M. H., and Vignati, E.: Production of sea spray aerosol in the surf zone, J. Geophys. Res., 105, 29397-29409, 2000.

Fuentes, E., Coe, H., Green, D., de Leeuw, G., and McFiggans, G.: Laboratory-generated primary marine aerosol via bubblebursting and atomization, Atmos. Meas. Tech., 3, 141-162, doi:10.5194/amt-3-141-2010, 2010.

Generoso, S., Bey, I., Labonne, M., and Bréon, F.-M.: Aerosol vertical distribution in dust outflow over the Atlantic: Compar- 
isons between GEOS-Chem and Cloud-Aerosol Lidar and Infrared Pathfinder Satellite Observation (CALIPSO), J. Geophys. Res., 113, D24209, doi:10.1029/2008JD010154, 2008.

Gerber, H. E.: Relative-humidity parameterization of the Navy Aerosol Model (NAM), NRL Report 8956, Naval Research Laboratory, Washington, DC, 1985.

Gong, S. L.: A parameterization of sea-salt aerosol source function for sub- and super-micron particles, Global Biogeochem. Cy., 17(4), 1097, doi:10.1029/2003GB002079, 2003.

Gong, S. L, Barrie, L. A., and Blanchet, J.-P.: Modeling sea-salt aerosols in the atmosphere 1. Model development, J. Geophys. Res., 102(D3), 3805-3818, 1997a.

Gong, S. L., Barrie, L. A., Prospero, J. M., Savoie, D. L., Ayers, G. P., Blanchet, J.-P., and Spacek, L.: Modeling sea-salt aerosols in the atmosphere 2. Atmospheric concentrations and fluxes, J. Geophys. Res., 102(D3), 3819-3830, 1997b.

Grini, A., Myhre, G., Sundet, J. K., and Isaksen, I. S. A.: Modeling the annual cycle of sea salt in the global 3-D model Oslo CTM2: Concentrations, fluxes, and radiative impact, J. Climate, 15, 1717-1730, 2002.

Guelle, W., Schulz, M., and Balkanski, Y.: Influence of the source formulation on modeling the atmospheric global distribution of sea salt aerosol, J. Geophys. Res., 106, 27509-27524, 2001.

Hainsworth, A. H. W., Dick, A. L., and Gras, J. L.: Climatic context of the First Aerosol Characterization Experiment (ACE 1): A meteorological and chemical overview, J. Geophys. Res., 103, 16319-16340, 1998.

Hansen, J., Sato, M., Ruedy, R., Lo, K., Lea, D. W., and MedinaElizade, M.: Global temperature change, P. Natl. Acad. Sci., 103, 14288-14293, doi:10.1073/pnas.0606291103, 2006.

Haywood, J., Ramaswamy, V., and Soden, B.: Tropospheric aerosol climate forcing in clear sky satellite observation over the oceans, Science, 283, 1299-1303, 1999.

Henderson, B. G., Chylek, P., Porch, W. M., and Dubey, M.: Satellite remote sensing of aerosols generated by the Island of Nauru, J. Geophys. Res., 111, D22209, doi:10.1029/2005JD006850, 2006.

Holben, B. N., Eck, T. F., Slutsker, I., Tanré, D., Buis, J. P., Setzer, A., Vermote, E., Reagan, J. A., Kaufman, Y. J., Nakajima, T., Lavenu, F., Jankowiak, I., and Smirnov, A.: AERONET-A federated instrument network and data archive for aerosol characterization, Remote Sens. Environ., 66, 1-16, doi:10.1016/S00344257(98)00031-5, 1998.

Holmes, C. D., Jacob, D. J., and Yang, X.: Global lifetime of elemental mercury against oxidation by atomic bromine in the free troposphere, Geophys. Res. Lett., 33, L20808, doi:10.1029/2006GL027176, 2006.

Hsu, S. A., Meindl, E. A., and Gilhousen, D. B.: Determining the power law wind-profile exponent under near-neutral stability conditions at sea, Appl. Meteorol., 33(6), 757-765, 1994.

Kahn, R. A., Garay, M. J., Nelson, D. L., Yau, K. K., Bull, M. A., Gaitley, B. J., Martonchik, J. V., and Levy ,R. C.: Satellite-derived aerosol optical depth over dark water from MISR and MODIS: Comparisons with AERONET and implications for climatological studies, J. Geophys. Res., 112, D18205, doi:10.1029/2006JD008175, 2007.

Kalnay, E., Kanamitsu, M., Kistler, R., Collins, W., Deaven, D., Gandin, L., Iredell, M., Saha, S., White, G., Woollen, J., Zhu, Y., Chelliah, M., Ebisuzaki, W., Higgins, W., Janowiak, J., Mo, K.
C., Ropelewski, C., Wang, J., Leetmaa, A., Reynolds, R., Jenne, R., and Joseph, D.: The NCEP/NCAR 40-year reanalysis project, B. Am. Meteorol. Soc., 77, 437-470, 1996.

Kaufman, Y., Remer, L., Tanré, D., Li, R.-R., Kleidman, R., Mattoo, S., Levy, R., Eck, T., Holben, B., Ichoku, C., Martins, J., and Koren, I.: A critical examination of residual cloud contamination and diurnal sampling effects on MODIS estimates of aerosol over ocean, IEEE T. Geosci. Remote, 43, 2886-2897, 2005.

Kinne, S., Schulz, M., Textor, C., Guibert, S., Balkanski, Y., Bauer, S. E., Berntsen, T., Berglen, T. F., Boucher, O., Chin, M., Collins, W., Dentener, F., Diehl, T., Easter, R., Feichter, J., Fillmore, D., Ghan, S., Ginoux, P., Gong, S., Grini, A., Hendricks, J., Herzog, M., Horowitz, L., Isaksen, I., Iversen, T., Kirkevåg, A., Kloster, S., Koch, D., Kristjansson, J. E., Krol, M., Lauer, A., Lamarque, J. F., Lesins, G., Liu, X., Lohmann, U., Montanaro, V., Myhre, G., Penner, J., Pitari, G., Reddy, S., Seland, O., Stier, P., Takemura, T., and Tie, X.: An AeroCom initial assessment - optical properties in aerosol component modules of global models, Atmos. Chem. Phys., 6, 1815-1834, doi:10.5194/acp-6-1815-2006, 2006.

Kleefeld, C., O’Dowd, C. D., O’Reilly, S., Jennings, S. G., Aalto, P., Becker, E., Kunz, G., and de Leeuw, G.: Relative contribution of submicron and supermicron particles to aerosol light scattering in the marine boundary layer, J. Geophys. Res., 107(D19), 8103, doi:10.1029/2000JD000262, 2002.

Köpke, P., Hess, M., Schult, I., and Shettle, E. P.: Global aerosol datatset, report, Max-Planck Inst. für Meteorol., Hamburg, Germany, 1997.

Korhonen, H., Carslaw, K. S., Forster, P. M., Mikkonen, S., Gordon, N. D., and Kokkola, H.: Aerosol climate feedback due to decadal increases in Southern Hemisphere wind speeds, Geophy. Res. Lett., 37, L02805, doi:10.1029/2009GL041320, 2010.

Latham, J. and Smith, M. H.: Effect on global warming of winddependent aerosol generation at the ocean surface, Nature, 347, 372-373, 1990.

Lee, Y. H. and Adams, P. J.: Evaluation of aerosol distributions in the GISS-TOMAS global aerosol microphysics model with remote sensing observations, Atmos. Chem. Phys., 10, 2129-2144, doi:10.5194/acp-10-2129-2010, 2010.

Levy, R. C., Remer, L. A., Tanré, D., Kaufman, Y. J., Ichoku, C., Holben, B. N., Livingston, J. M., Russell, P. B., and Maring, H.: Evaluation of the Moderate-Resolution Imaging Spectroradiometer (MODIS) retrievals of dust aerosol over the ocean during PRIDE, J. Geophys. Res., 108(D19), 8594, doi:10.1029/2002JD002460, 2003.

Levy, R. C., Leptoukh, G. G., Kahn, R., Zubko, V., Gopalan, A., and Remer, L. A.: A Critical Look at Deriving Monthly Aerosol Optical Depth From Satellite Data, IEEE T. Geosci. Remote, 47, 2942-2956, 2009.

Lewis, E. R. and Schwartz, S. E.: Sea Salt Aerosol Production: Mechanisms, Methods, Measurements, and Models: A Critical Review, American Geophysical Union, Washington, DC, 2004.

Liao, H., Seinfeld, J. H., Adams, P. J., and Mickley, L. J.: Global radiative forcing of coupled tropospheric ozone and aerosols in a unified general circulation model, J. Geophys. Res., 109, D16207, doi:10.1029/2003JD004456, 2004.

Lin, J.-T. and McElroy, M.: Impacts of boundary layer mixing on pollutant vertical profiles in the lower troposphere: Implications to satellite remote sensing, Atmos. Environ., 44(14), 1726-1739, 
doi:10.1016/j.atmosenv.2010.02.009, 2010.

Liu, H., Jacob, D. J., Bey, I., and Yantosca, R. M.: Constraints from ${ }^{210} \mathrm{~Pb}$ and ${ }^{7} \mathrm{Be}$ on wet deposition and transport in a global threedimensional chemical tracer model driven by assimilated meteorological fields, J. Geophys. Res., 106, 12109-12128, 2001.

Liu, X., Penner, J. E., Das, B., Bergmann, D., Rodriguez, J. M., Strahan, S., Wang, M., and Feng, Y.: Uncertainties in global aerosol simulations: Assessment using three meteorological data sets, J. Geophys. Res., 112, D11212, doi:10.1029/2006JD008216, 2007.

Ma, X., von Salzen, K., and Li, J.: Modelling sea salt aerosol and its direct and indirect effects on climate, Atmos. Chem. Phys., 8, 1311-1327, doi:10.5194/acp-8-1311-2008, 2008.

Mahowald, N., Lamarque, J.-F., Tie, X., Wolff, E.: Sea salt aerosol response to climate change: last glacial maximum, pre-industrial and doubled carbon dioxide climates, J. Geophys. Res., 111, D05303, doi:10.1029/2005JD006459, 2006.

Mårtensson, E. M., Nilsson, E. D., de Leeuw, G., Cohen, L. H., and Hansson, H.-C.: Laboratory simulations and parameterizations of the primary marine aerosol productions, J. Geophys. Res., 108, 4297, doi:10.1029/2002JD002263, 2003.

Martin, R. V., Jacob, D. J., Yantosca, R. M., Chin, M., and Ginoux, P.: Global and regional decreases in oxidants from photochemical effects of aerosols, J. Geophys. Res., 108, 4097, doi:10.1029/2002JD002633, 2003.

Meehl, G. A. and Stocker, T. F.: Global Climate Projections, in: Climate Change 2007: The Physical Science Basis, Contribution of Working Group I to the Fourth Assessment Report of the Intergovernmental Panel on Climate Change, edited by: Solomon, S., Qin, D., Manning, M., Chen, Z., Marquis, M., Averyt, K. B., Tignor, M., and Miller, H. L., Cambridge University Press, Cambridge, United Kingdom and New York, NY, USA, 2007.

Mohanan, E. C. and O'Muircheartaigh, I. G.: Optimal power-law description of oceanic whitecap coverage dependence on wind speed, J. Phys. Ocean., 10, 2094-2099, 1980.

Monahan, E. C., Spiel, D. E., and Davidson, K. L.: A model of marine aerosol generation via whitecaps and wave disruption in oceanic whitecaps, in: Oceanic whitecaps and their role in air-sea exchange processes, edited by: Monahan, E. C. and Niocaill, G. M., D. Reidel Publishing, Dordrecht, Holland, 167-174, 1986.

Murphy, D. M., Anderson, J. R., Quinn, P. K., McInnes, L. M., Brechtel, F. J., Kreidenweis, S. M., Middlebrook, A. M., Pósfai, M., Thomson, D. S., and Buseck, P. R.: Influence of sea-salt on aerosol radiative properties in the Southern Ocean marine boundary layer, Nature 392, 62-65, doi:10.1038/32138, 1998.

MWF, Mean Wind Fields (MWF product) - User Manual - Volume 2 : QuikSCAT, C2-MUT-W-04-IF, CERSAT - IFREMER, available at: http://www.ifremer.fr/cersat/en/data/overview/gridded/ mwfqscat.htm, 2002.

O'Dowd, C. D. and Smith, M. H.: Physicochemical Properties of Aerosols Over the Northeast Atlantic: Evidence for Wind-SpeedRelated Submicron Sea-Salt Aerosol Production, J. Geophys. Res., 98(D1), 1137-1149, doi:10.1029/92JD02302, 1993.

O'Dowd, C. D., Smith, M. H., Consterdine, I. E., and Lowe, J. A.: Marine aerosol, sea salt, and the marine sulphur cycle: A short review, Atmos. Environ., 31, 73-80, 1997.

Park, R. J., Jacob, D. J., Field, B. D., Yantosca, R. M., and Chin, M.: Natural and transboundary pollution influences on sulfate-nitrate-ammonium aerosols in the United
States: Implications for policy, J. Geophys. Res., 109, D15204, doi:10.1029/2003JD004473, 2004.

Penner, J. E., Zhang, S. Y., Chin, M., Chuang, C. C., Feichter, J., Feng, Y., Geogdzhayev, I. V., Ginoux, P., Herzog, M., Higurashi, A., Koch, D., Land, C., Lohmann, U., Mishchenko, M., Nakajima, T., Pitari, G., Soden, B., Tegen, I., and Stowe, L.: A comparison of model- and satellite-derived aerosol optical depth and reflectivity, J. Atmos Sci., 59(3), 441-460, 2002.

Pierce, J. R. and Adams, P. J.: Global evaluation of CCN formation by direct emission of sea salt and growth of ultrafine sea salt, J. Geophys. Res., 111, D06203, doi:10.1029/2005JD006186, 2006.

Quinn, P. K. and Bates, T. S.: Regional aerosol properties: Comparisons of boundary layer measurements from ACE 1, ACE 2, aerosols99, INDOEX, ACE asia, TARFOX, and NEAQS, J. Geophys. Res., 110(D14), D14202, doi:10.1029/2004JD004755, 2005.

Quinn, P. K., Coffman, D. J., Kapustin, V. N., Bates, T. S., and Covert, D. S.: Aerosol optical properties in the marine boundary layer during the First Aerosol Characterization Experiment (ACE 1) and the underlying chemical and physical aerosol properties, J. Geophys. Res., 103(D13), 16547-16563, 1998.

Quinn, P. K., Kupustin, V. N., Bates, T. S., and Covert, D. S.: Chemical and optical properties of marine boundary layer aerosol particles of the mid-Pacific in relation to sources and meteorological transport, optical properties of sea salt aerosols, J. Geophys. Res., 102, 23269-23275, 1996.

Quinn, P. K. and Coffman, D. J.: Comment on "Contribution of different aerosol species to the global aerosol extinction optical thickness: Estimates from model results" by Tegen, I., Hollrig, P., Chin, M., Fung, I., Jacob, D., and Penner, J., J. Geophys. Res., 104(D4), 4241-4248, 1999.

Quinn, P. K., Coffman, D. J., Bates, T. S., Miller, T. L., Johnson, J. E., Voss, K., Welton, E. J., and Neusüss, C.: Dominant aerosol chemical components and their contribution to extinction during the Aerosols99 cruise across the Atlantic, J. Geophys. Res., 106, 20783-20809, doi:10.1029/2000JD900577, 2001.

Read, K. A., Mahajan, A. S., Carpenter, L. J., Evans, M. J., Faria, B. V. E., Heard, D. E., Hopkins, J. R., Lee, J. D., Moller, S. J., Lewis, A. C., Mendes, L., McQuaid, J. B., Oetjen, H., SaizLopez, A., Pilling M. J., and Plane, J. M. C.: Extensive halogenmediated ozone destruction over the tropical Atlantic Ocean, Nature, 453, 1232-1235, 2008.

Reid, J. S. and Peters, T. M.: Update to "Reconciliation of coarse mode sea-salt aerosol particle size measurements and parameterizations at a subtropical ocean receptor site" regarding the use of aerodynamic particle sizers in marine environments, J. Geophys. Res., 112, D04202, doi:10.1029/2006JD007501, 2007.

Reid, J. S., Brooks, B., Crahan, K. K., Hegg, D. A., Eck, T. F., O'Neill, N., de Leeuw, G., Reid, E. A., and Anderson, K. D.: Reconciliation of coarse mode sea-salt aerosol particle size measurements and parameterizations at a subtropical ocean receptor site, J. Geophys. Res., 111, D02202, doi:10.1029/2005JD006200, 2006.

Remer, L. A., Kleidman, R. G., Levy, R. C., Kaufman, Y. J., Tanre, D., Mattoo, S., Martins, J. V., Ichoku, C., Koren, I., Yu, H., and Holben, B. N.: Global aerosol climatology from the MODIS satellite sensors, J. Geophys. Res., 113(D14), D14S07, doi:10.1029/2007JD009661, 2008.

Reynolds, R. W., Rayner, N. A., Smith, T. M., Stokes, D. C., and 
Wang, W.: An improved in situ and satellite SST analysis for climate, J. Clim., 15, 1609-1625, 2002.

Savoie, D. L. and Prospero, J. M.: Aerosol Concentration Statistics for the Northern Tropical Atlantic, J. Geophys. Res., 82(37), 5954-5964, doi:10.1029/JC082i037p05954, 1977.

Sellegri, K., O’Dowd, C. D., Yoon, Y. J., Jennings, S. G., and de Leeuw, G.: Surfactants and submicron sea spray generation, J. Geophys. Res., 111, D22215, doi:10.1029/2005JD006658, 2006.

Shinozuka, Y., Clarke, A. D., Howell, S. G., Kapustin, V. N., and Huebert, B. J.: Sea-salt vertical profiles over the Southern and tropical Pacific oceans: Microphysics, optical properties, spatial variability, and variations with wind speed, J. Geophys. Res., 109, D24201, doi:10.1029/2004JD004975, 2004.

Sievering, H., Boatman, J., Gorman, E., Kim, Y., Anderson, L., Ennis, G., Luria, M., and Pandis, S.: Removal of sulfur from the marine boundary layer by ozone oxidation in sea-salt aerosols, Nature, 360, 571-573, 1992.

Slinn, W. G. N.: Predictions for particle deposition to vegetative canopies, Atmos. Environ., 16, 1785-1794, 1982.

Slinn, S. A. and Slinn, W. G. N.: Predictions for particle deposition on natural-waters, Atmos. Environ., 14, 1013-1016, 1980.

Smirnov, A., Holben, B. N., Eck, T. F., Dubovik, O., and Slutsker, I.: Cloud screening and quality control algorithms for the AERONET data-base, Remote Sens. Environ., 73, 337-349, doi:10.1016/S0034-4257, 2000.

Smirnov, A.; Holben, B. N., Slutsker, I., Giles, D. M., McClain, C. R., Eck, T. F., Sakerin, S. M., Macke, A., Croot, P., Zibordi, G., Quinn, P. K., Sciare, J., Kinne, S., Harvey, M. J., Smyth, T. J., Piketh, S., Zielinski, T., Proshutinsky, A., Goes, J. I., Nelson, N. B., Larouche, P., Radionov, V. F., Goloub, P., Moorthy, K. K., Matarrese, R., Robertson, E. J., and Jourdin, F.: Maritime Aerosol Network as a component of Aerosol Robotic Network, J. Geophys. Res., 114, D06204, doi:10.1029/2008JD011257, 2009.

Smith, M. H. and Harrison, N. M.: The sea spray generation function, J. Aerosol Sci., 29, Suppl. 1, S189-S190, 1998.

Takemura, T., Okamoto, H., Maruyama, Y., Numaguti, A., Higurashi, A., and Nakajima, T.: Global three-dimensional simulation of aerosol optical thickness distribution of various origins, J. Geophys. Res., 105(D14), 17853-17873, doi:10.1029/2000JD900265, 2000.

Textor, C., Schulz, M., Guibert, S., Kinne, S., Balkanski, Y., Bauer, S., Berntsen, T., Berglen, T., Boucher, O., Chin, M., Dentener, F., Diehl, T., Easter, R., Feichter, H., Fillmore, D., Ghan, S., Ginoux, P., Gong, S., Grini, A., Hendricks, J., Horowitz, L., Huang, P., Isaksen, I., Iversen, I., Kloster, S., Koch, D., Kirkevåg, A., Kristjansson, J. E., Krol, M., Lauer, A., Lamarque, J. F., Liu, X., Montanaro, V., Myhre, G., Penner, J., Pitari, G., Reddy, S., Seland, O., Stier, P., Takemura, T., and Tie, X.: Analysis and quantification of the diversities of aerosol life cycles within AeroCom, Atmos. Chem. Phys., 6, 1777-1813, doi:10.5194/acp-61777-2006, 2006.
Textor, C., Schulz, M., Guibert, S., Kinne, S., Balkanski, Y., Bauer, S., Berntsen, T., Berglen, T., Boucher, O., Chin, M., Dentener, F., Diehl, T., Feichter, J., Fillmore, D., Ginoux, P., Gong, S., Grini, A., Hendricks, J., Horowitz, L., Huang, P., Isaksen, I. S. A., Iversen, T., Kloster, S., Koch, D., Kirkevåg, A., Kristjansson, J. E., Krol, M., Lauer, A., Lamarque, J. F., Liu, X., Montanaro, V., Myhre, G., Penner, J. E., Pitari, G., Reddy, M. S., Seland, O., Stier, P., Takemura, T., and Tie, X.: The effect of harmonized emissions on aerosol properties in global models an AeroCom experiment, Atmos. Chem. Phys., 7, 4489-4501, doi:10.5194/acp-7-4489-2007, 2007.

Tsigaridis, K., Koch, D., and Menon, S.: Influences of the primary organic marine component on sea-spray composition and climate, Abstract \#A41H-10 presented at the 2010 Fall Meeting, AGU, San Francisco, Calif., 13-17 December, 2010.

Tyree, C. A., Hellion, V. M., Alexandrova, O. A., and Allen, J. O.: Foam droplets generated from natural and artificial seawaters, J. Geophys. Res., 112, D12204, doi:10.1029/2006JD007729, 2007.

Vogt, R., Sander, R., von Glasow, R., and Crutzen, P. J.: Iodine chemistry and its role in halogen activation and ozone loss in the marine boundary layer: A model study, J. Atmos. Chem., 32, 375-395, 1999.

von Glasow, R., von Kuhlmann, R., Lawrence, M. G., Platt, U., and Crutzen, P. J.: Impact of reactive bromine chemistry in the troposphere, Atmos. Chem. Phys., 4, 2481-2497, doi:10.5194/acp4-2481-2004, 2004.

Winter, B. and Chylek, P.: Contribution of sea salt aerosol to the planetary clear-sky albedo, Tellus B, 49(1), 72-79, 1997.

Witek, M. L., Flatau, P. J., Quinn, P. K., and Westphal, D. L.: Global sea-salt modeling: Results and validation against multicampaign shipboard measurements, J. Geophys. Res., 112, D08215, doi:10.1029/2006JD007779, 2007.

Woolf, D. K., Bowyer, P. A., and Monahan, E. C.: Discriminating between the film drops and jet drops produced by a simulated whitecap, J. Geophys. Res., 92, 5142-5150, 1987.

Yang, X., Cox, R. A., Warwick, N. J., Pyle, J. A., Carver, G. D., O'Connor, F. M., and Savage, N. H.: Tropospheric bromine chemistry and its impacts on ozone: A model study, J. Geophys. Res., 110, D23311, doi:10.1029/2005JD006244, 2005.

Zhang, J. and Reid, J. S.: MODIS aerosol product analysis for data assimilation: Assessment of over-ocean level 2 aerosol optical thickness retrievals, J. Geophys. Res., 111, D22207, doi:10.1029/2005JD006898, 2006.

Zhang, L., Gong, S., Padro, J., and Barrie, L.: A size-segregated particle dry deposition scheme for an atmospheric aerosol module, Atmos. Environ., 35, 549-560, 2001.

Zhang, J., Reid, J. S., and Holben, B. N.: An analysis of potential cloud artifacts in MODIS over ocean aerosol optical thickness products, Geophys. Res. Lett., 32, L15803, doi:10.1029/2005GL023254, 2005. 